NBER WORKING PAPER SERIES

\title{
MIGRATION, SPILLOVERS, AND TRADE DIVERSION: THE IMPACT OF INTERNALIZATION ON STOCK MARKET LIQUIDITY
}

\author{
Ross Levine \\ Sergio L. Schmukler \\ Working Paper 9614 \\ http://www.nber.org/papers/w9614
NATIONAL BUREAU OF ECONOMIC RESEARCH 1050 Massachusetts Avenue
Cambridge, MA 02138
April 2003

\begin{abstract}
We received very helpful comments from Gordon Alexander, Luca Benzoni, Stijn Claessens, Valery Polknichenko, Helene Rey, and Frank Warnock. For help with the data, we are grateful to Pamela Dottin, Monica Erpen, Dori Flanagan, Angela Marshall, Richard Webster-Smith, and Cheryl Workman. Levine is grateful for generous financial support from the BSI Gamma Foundation. Schmukler thanks the World Bank Latin American Regional Studies Program and Research Support Budget for financial support. The findings, interpretations, and conclusions expressed in this paper are entirely those of the authors and do not necessarily represent the views of the World Bank. The views expressed herein are those of the authors and not necessarily those of the National Bureau of Economic Research.
\end{abstract}

(C2003 by Ross Levine and Sergio L. Schmukler. All rights reserved. Short sections of text not to exceed two paragraphs, may be quoted without explicit permission provided that full credit including Onotice, is given to the source. 
Migration, Spillovers, and Trade Diversion:

The Impact of Internalization on Stock Market Liquidity

Ross Levine and Sergio L. Schmukler

NBER Working Paper No. 9614

April 2003

JEL No. G15, F36, F20

\begin{abstract}
What is the impact of firms that cross-list, issue depositary receipts, or raise capital in international stock markets on the liquidity of remaining firms in domestic markets? Using a panel of over 3,200 firms from 55 countries during 1989-2000, we find that internationalization reduces the liquidity of domestic firms through two channels. First, the trading of international firms migrates from domestic to international markets and the reduction in domestic liquidity of international firms has negative spillover effects on domestic firm liquidity. Second, there is trade diversion within domestic markets as liquidity shifts out of domestic firms and into international firms.
\end{abstract}

Ross Levine Finance Department

Carlson School of Management

University of Minnesota

$32119^{\text {th }}$ Avenue South

Minneapolis, MN 55455

and NBER

rlevine@econ.umn.edu
Sergio L. Schmukler

World Bank

1818 H Street, NW

Washington, DC 20433

sschmukler@worldbank.org 


\section{Introduction}

This paper assesses the question: what is the impact of firms that participate in international stock markets on the liquidity of the remaining firms in the domestic stock market? An extensive literature examines "international firms," the firms that participate in international markets by issuing depositary receipts, cross-listing, or raising new capital (e.g., Alexander, Eun, and Janakirananan, 1987, 1988; Foerster and Karolyi, 1998, 1999, 2000; Miller, 1999; Doidge, Karolyi, and Stulz, 2002; and the review by Karolyi, 1998). This paper, instead, focuses on the impact of internationalization on "domestic firms," the firms that do not internationalize.

Theory provides conflicting predictions about the impact of internationalization on the liquidity of domestic firms. Consider first the "migration and spillover" argument. According to the migration view, internationalization will induce a shift in the trading of international firms out of the domestic market and into international markets. This may occur because foreign markets have lower transaction costs and are more liquid (Chowdhry and Nanda, 1991). "Spillovers" means that a drop in the domestic trading of international firms hurts the liquidity of domestic firms. ${ }^{1}$ This could occur because of fixed costs associated with operating a market, running brokerage firms, clearing and settling transactions, etc. Thus, a drop in the domestic trading of international stocks increases the per trade cost of domestic stock transactions. Liquidity spillovers could also occur if investors shift their trading to international markets. For example, investors may seek to diversify country-specific risk. Thus, when some firms cross-list or issue depositary receipts in international markets, investors may attain country-specific diversification through these liquid international markets and therefore reduce their trading in

\footnotetext{
${ }^{1}$ Chordia, Roll, and Subrahmanyam (2000) argue that liquidity is more than an attribute of a single security. Individual liquidity tends to co-move with market liquidity.
} 
domestic markets. ${ }^{2}$ This involves a shift out of trading domestic stocks on domestic exchanges and into trading internationalized stocks on international exchanges. Combined, migration and spillovers imply that internationalization reduces the domestic liquidity of international firms due to migration, and the resultant drop in aggregate domestic liquidity reduces the liquidity of domestic firms due to spillovers.

Some disagree with the migration and liquidity spillover view and instead argue that internationalization improves domestic market liquidity. In contrast to the migration view, Hargis (2000) argues that cross-listing can transform a segmented equity market with low liquidity into an integrated market with high liquidity. Similarly, Alexander, Eun, and Janakiramanan (1987) and Domowitz, Glen, and Madhavan (1998) hold that internationalization may actually stimulate domestic trading of international firms due to the increased integration of markets. Also, if internationalization increases transparency, this could increase the domestic trading of international firms with positive spillover effects for the rest of the domestic market. Other skeptics of the migration spillover view could question the existence of liquidity spillovers, or doubt the economic importance of the impact of aggregate trading on the liquidity of domestic firms. Thus, it is an empirical question as to whether internationalization induces migration and spillovers, or whether internationalization boosts the liquidity of domestic firms.

Second, consider the "domestic trade diversion" view, which argues that internationalization induces a compositional shift in domestic market trading. Firms that internationalize may become more attractive to those trading in domestic markets because of improvements in reputation, higher disclosure standards, the availability of more analysts that generate more information, and the expansion of the shareholder base in the context of

\footnotetext{
${ }^{2}$ Ahearne, Griever, and Warnock (2003) and Edison and Warnock (2003) show that U.S. investors focus on firms that have internationalized.
} 
segmented markets. ${ }^{3}$ Thus, traders in the domestic market may shift their trading out of domestic firms and into the domestic trading of international firms. All else equal, this domestic trade diversion implies less trading of domestic firms and greater trading of international firms in the domestic market. However, some theories conflict with the trade diversion view and instead argue that internationalization may enhance integration and thereby boost liquidity of domestic firms (e.g., Alexander, et al., 1987; Domowitz, et al., 1998; Hargis, 2000). This could occur because integration increases the liquidity of all firms in the local markets. Moreover, integration may induce a compositional shift in domestic market liquidity toward domestic firms as the trading of international firms migrates abroad. Again, theory provides conflicting predictions about the impact of firms that choose to internationalize on domestic firms.

To study the effects of internationalization on domestic liquidity, this paper uses information on 3,253 domestic firms and 640 international firms across 55 emerging market countries during the years 1989 to 2000 . To measure liquidity, we use the turnover ratio, which equals the value of a firm's transactions in a market divided by the market capitalization of the firm in the domestic market. We use transactions data because bid-ask spreads are unavailable for our large panel of countries.

The paper first examines the direct impact of internationalization on the liquidity of domestic firms. Using annual, firm-level data, we regress the liquidity of domestic firms on the share of international firms in the domestic market as well as country and year dummy variables. While we cannot eliminate the possibility that an omitted factor is driving the results, we can control for an array of firm-specific and country specific traits. We do a variety of robustness checks controlling for firm-specific characteristics (such as firm size, sales, firm profits, the

\footnotetext{
${ }^{3}$ See, Baker, Nofsinger, and Weaver (2002), Coffee (1999), Lang, Lins, and Miller (2002), Merton (1987), Portes and Rey (1999), and Reese and Weisbach (2001). Also, Bailey, Karolyi, and Salva (2002) find that earnings releases impact the price and volume of international firms significantly more than domestics firms.
} 
firm's industry etc.) and various country-specific factors (e.g., trading of that country's shares on international exchanges, economic development, legal system efficiency, international capital flow openness, inflation, etc.). The results are consistent across numerous specifications.

The data indicate that as more firms become international, this lowers the liquidity of domestic firms. This result is robust to controlling for numerous firm-specific and countryspecific traits. These initial results, however, do not shed light on the mechanisms through which internationalization hurts the liquidity of domestic firms.

Next, the paper studies the channels through which international firms affect the liquidity of domestic firms. We study both the (1) migration and liquidity spillover channel and (2) the domestic trade diversion channel. Thus, we seek to explain the mechanisms through which internationalization influences the liquidity of domestic firms.

To study the migration and liquidity spillover channel, we (a) assess whether the trading of international firms migrates from domestic to international markets and (b) test whether the domestic trading of international firms influences the liquidity of domestic firms. We find evidence of migration: as the fraction of international firms rises, the trading of international firms shifts from domestic markets to international markets. That is, as more firms internationalize, domestic liquidity of international firms falls. Furthermore, we find evidence of liquidity spillovers. The domestic trading of international shares is strongly, positively related to the liquidity of domestic firms. Thus, the data are consistent with migration and spillover view: as the liquidity of international firms in the domestic market dries up because of migration, the liquidity of domestic firms diminishes because of spillovers.

The migration and liquidity spillover channel, however, is not the only mechanism through which internationalization hurts the liquidity of domestic firms. In particular, we find 
that internationalization is negatively associated with the liquidity of domestic firms even after controlling for the migration and spillover channel. Thus, we need to look beyond migration and spillovers to understand fully the impact of internationalization on the domestic market.

Finally, we examine the domestic trade diversion channel. The data suggest that as firms internationalize, the domestic market intensifies its trading of those international shares, while trading of firms that do not internationalize wanes. This does not overturn the result mentioned above: internationalization reduces the domestic liquidity of international shares. This result is consistent with theories that emphasize that when a firm internationalizes this enhances its reputation, transparency, and shareholder base in ways that make it more attractive relative to domestic firms. In sum, domestic trade diversion is another mechanism through which internationalization reduces the liquidity firms that do not internationalize.

This paper's assessment of the impact of internationalization on the liquidity of domestic firms is related to, though distinct from, a large literature on internationalization. First, some research analyzes the impact of market integration on economic growth, investment, and asset pricing. ${ }^{4}$ In this paper, we do not focus on financial integration broadly defined. Rather, we examine the impact of the decision of one set of firms to cross-list, issue depositary receipts, or raise capital abroad on the liquidity of the domestic firms that do not internationalize. ${ }^{5}$ Second, an extensive literature studies the effects of internationalization on international firms. Some papers examine the volume and liquidity of international firms in local markets after firms crosslist or issue depositary receipts. ${ }^{6}$ Other researchers study the impact of internationalization on

\footnotetext{
${ }^{4}$ See Bekaert and Harvey (1995, 2000), Bekaert, Harvey, and Lundblad (2001, 2002), Henry (2000), Levine and Zervos (1998a,b), and Martin and Rey (2000).

${ }^{5}$ Various publications voice concerns of markets becoming illiquid (e.g., Bovespa, 1996; Financial Times, 1998; and Latin Finance, 1999; The Economist, 2000; and the Federation des Bourses de Valeurs, 2000).

${ }^{6}$ See Foerster and Karolyi (1998, 2000), Hargis (1998), Noronha, Sarin, and Saudagaran (1996), and Pulatkonak and Sofianos (1999).
} 
stock prices, the cost of capital, and growth opportunities. ${ }^{7}$ A related line of research analyzes the effect of internationalization on asset size, growth, financing constraints, and the financial structure of firms that issue depositary receipts or cross-list. ${ }^{8}$ Although in the course of our research we assess the impact of the liquidity of international firms on the domestic liquidity of those international firms, the focus of our research is different. We concentrate on examining the impact of internationalization on the liquidity of domestic firms.

Only two previous studies examine specifically the effects of internationalization on domestic firms. Moel (2001) finds a negative association between the fraction of a country's stocks that issue American depositary receipts (ADRs) and domestic market liquidity. Karolyi (2003) also finds a negative link between ADRs and domestic market size and liquidity.

This paper contributes to the literature on internationalization and the liquidity of domestic stocks in a number of ways. First, this is the first paper to dissect the channels through which internationalization influences the liquidity of domestic stocks. Thus, we evaluate the importance of the migration/spillover channel and the trade diversion channel. Second, in examining the potential channels through which internationalization influences domestic stock liquidity, we examine the impact of firms that internationalize on both (a) the trading of international firms in the domestic market and (b) the liquidity of domestic firms. Thus, besides contributing to the recent literature on the effects of internationalization on domestic firms, we also use our new database to augment the more established literature on international firms. Third, we substantially expand the sample size. Our data cover 55 countries, which almost doubles the number of countries used in previous studies (e.g., Moel, 2001, examines 28

\footnotetext{
${ }^{7}$ See Alexander, Eun, and Janakiramanan (1988), Demirguc-Kunt and Maksimovic (1998), Errunza and Miller (2000), Foerster and Karolyi (1993, 1999), Miller (1999) and Stulz (1999).

${ }^{8}$ See Claessens, Klingebiel, and Schmukler (2002a), Pagano, Roell, and Zechner (2002), and Schmukler and Vesperoni (2001).
} 
countries and Karolyi, 2003, studies 12). Fourth, we extend the coverage of the internationalization process by moving beyond the ADR market in New York. Specifically, we compile data on capital raisings that include global depositary receipts, cross-listings, and private placements in other international markets. Thus, we can more precisely classify companies as international or domestic. Fifth, we collect information on the international trading activities of international firms. That is, we do not simply examine whether a firm is listed abroad or not; we incorporate time-vary trading data. This has two advantages: (a) we control for country-specific news that influences global trading of that country's shares and (b) we assess how the timevarying extent of internationalization impacts domestic markets. Sixth, we control for firm specific characteristics, including firm size and other traits, to isolate the marginal impact of internationalization on firm liquidity while holding firm-specific factors constant.

Finally, we stress a limitation of this paper's analyses. We find that internationalization reduces the liquidity of domestic firms. We do not, however, examine the net effect of internationalization (Hargis and Ramanlal, 1998). Specifically, many researchers show that internationalization benefits those firms that choose to internationalize. Furthermore, research finds that domestic market liquidity is important for the cost of capital, firm performance, and economic growth. ${ }^{9}$ Thus, if internationalization helps international firms and hurts domestic firms, a critical question emerges: what is the net effect for the domestic economy of firms that cross-list, issue depositary receipts, or raise capital abroad? We leave this for future research.

The rest of the paper is organized as follows. Section II discusses the data. Section III presents the results. Section V concludes.

\footnotetext{
${ }^{9}$ See Amihud and Mendelson (1986), Demirguc-Kunt and Maksimovic (1998), Levine and Zervos (1998a), and Beck and Levine (2003).
} 


\section{Data}

To assess the impact of internationalization on domestic stocks, we need the following data:

1. firm-level data on the international equity activities of firms, including

a. dates of capital raisings, cross-listing, and depositary receipts,

b. international trading data,

2. firm-level data on domestic stock transactions,

3. firm-level data on a range of firm attributes, and

4. country-specific data on macroeconomic, institutional, and financial conditions.

An important contribution of this paper is that we collect considerably more data on the international equity market activities of companies than past studies. The data for identifying each firm's international activities come from two main sources: the Bank of New York and Euromoney.

Besides the Bank of New York's standard database (the Complete Depositary Receipt Directory) that contains information on current depositary receipt activities, the Bank of New York gave us access to their historical databases and reports on (i) depositary receipt program initiation dates, (ii) termination dates (if any), (iii) capital raisings, and (iv) trading activities. These data form a comprehensive database on American and Global depositary receipt programs. The historical data start in January 1956, but the vast majority of programs begin after 1980 .

We augment the information on dating the initiation of international equity market activities with data from Euromoney. They provide the dates when firms raise equity capital in international capital markets, including cross-listings and issuance of global depositary receipts. Thus, the Euromoney data substantively enhances our ability to identify firms that internationalize. The Euromoney database covers 8,795 cross-border equity issuance and crosslisting operations from 5,665 firms in 86 countries over the period January 1983 - April 2001. In terms of trading, we had access to data from the London and Frankfurt Stock Exchanges (LSE 
and FSE respectively) on the trading of depositary receipts and cross-listed firm. However, LSE trading data for these firms do not begin until 1997 and the data for the FSE do not start until 1999. Thus, they cannot be usefully incorporated into our panel studies that trace the impact of internationalization on the liquidity of domestic stocks and also assess the dynamic effects of trading in international markets on the domestic market. Thus, consistent with existing studies, we do not include LSE and FSE trading data. This will underestimate the amount of trading abroad, but this is unlikely to bias systematically the results in a particular direction. See Claessens, Klingebiel, and Schmukler (2002b) for a description of some trends on the internationalization of stock markets as well as their relation to country characteristics.

Consistent with our objective of assembling a broad database on internationalization, we classify firms as international if they (1) issue depositary receipts, (2) cross-list, or (3) raise capital through private placements abroad. The first two clearly involve ongoing trading of domestic stocks in foreign countries. However, raising capital through private placements is different because the new shares are not necessarily traded abroad. Thus, the issuing of depositary receipts and cross-listing may involve the two potential channels discussed in the Introduction: migration/spillovers and trade diversion. Raising capital abroad in the absence of cross-listing, however, will only potentially involve trade diversion in the domestic market since simply raising capital abroad cannot induce migration. As noted below, we confirm this paper's findings with various sub-samples.

The firm-level domestic stock market trading data are from the Standard \& Poor's Emerging Markets Data Base (EMDB), which was formerly collected by the International Finance Corporation. In cross-checking with country sources, the EMDB is very accurate, but for Argentina, we discovered that the EMDB information is inconsistent over time. Thus, unlike 
previous studies, we circumvent this problem by collecting the data directly from the Buenos Aires Stock Exchange. The EMDB provides data on domestic market capitalization and domestic value traded in current U.S. dollars by firm. Although the EMBD is the most comprehensive database on firm-level trading of equities around the world, the EMDB focuses mostly on emerging markets and does not include 100 percent of local firms (e.g., while varying by country, the EMDB typically covers about 70 percent of market capitalization).

We also use balance sheet data on each firm to control for firm-specific characteristics that may influence liquidity. Thus, we control for industry effects, firm size effects, and firm sales in assessing the impact of internationalization on the liquidity of firms in the domestic market. For simplicity, in the results discussed below, we present the results controlling for firm size, but the results are robust to controlling for the other firm-specific effects. We obtain these data from the Worldscope database (Thomson Financial Company).

The firm-level data on domestic stock market trading, the firm-level balance sheet information, and international equity activities are all matched at the firm level over the period 1989-2000. Appendix Table 1 lists the 55 countries in the study and the number of domestic and international firms per country, as well as summary statistics of the main variables under study. In total, we have over 18,000 firm-year observations. Appendix Table 2 provides additional information on data sources. ${ }^{10}$

As a robustness check, we also control for country-specific information. Data are from the World Bank's World Development Indicators. Data on the efficiency of each country's legal system are obtained from the International Country Risk Guide (Political Risk Services). Information on official restrictions on international capital flows is from the International

\footnotetext{
${ }^{10}$ Note, that some countries in our sample do not have any international firms. We keep these in the sample as a control sample. Importantly, we confirm this paper's results when we eliminate countries with zero or only one international firm.
} 
Monetary Fund's Annual Report on Exchange Arrangements and Exchange Restrictions. In additional tests, we control for economic growth, inflation, real interest rates, terms of trade changes, time trend, and alternative measures of capital account openness that we describe below.

Although our data have the limitations noted above, the database has several advantages over previous work. First, the data cover 55 countries, which - as we noted earlier - almost double the number of countries used in previous studies and increase the power of our tests. Second, our dataset includes information on the international equity market activities of firms beyond depositary receipts in New York. We collect information on issuance of equity, including cross-listing, in major financial markets. Thus, we can much more accurately identify which firms have internationalized. Third, we collect information on the international trading activities of each firm with a depositary receipt program. Thus, in assessing the impact of internationalization on domestic market liquidity, we move beyond considering whether a company has internationalized or not. By incorporating time-vary trading data, we can assess the dynamic effects of internationalization. 


\section{Methodology and Results}

This section empirically examines the impact of international firms, those that issue depositary receipts, cross-list, or raise new capital abroad, on domestic firms, those that do not internationalize. To do this, we first examine whether internationalization has a direct effect on the liquidity of domestic firms? Second, we examine whether internationalization affects domestic liquidity through the migration and spillover channel. Third, we test whether internationalization influences the liquidity of domestic firms through trade diversion.

\section{A. Direct Effect}

\section{Method}

To examine whether internationalization is directly related to the liquidity of domestic equities, we estimate the following regression using feasible generalized least squares with standard errors that are robust to heteroskedasticity.

$$
T_{j, c, t}^{D}=\gamma_{1} \times I S_{c, t}+\gamma_{2} \times I T_{c, t}^{I}+\theta^{\prime} M_{c, t}+\lambda_{1} \times F_{j, c, t}+\delta_{1} \times n_{c}+\delta_{2} \times \tau_{t}+\varepsilon_{j, c, t} .
$$

$T_{j, c, t}^{D}$ is the turnover ratio of domestic firm $\mathrm{j}$ in country $\mathrm{c}$ in year $\mathrm{t}$, which equals the total value of trades of firm j's stock during year t divided by firm j's market capitalization. ${ }^{11}$ The superscript $\mathrm{D}$ designates that it is a domestic firm during the entire sample period, i.e., it never internationalizes. We define the dependent variable in this way because we want to examine the effects of internationalization on the firms that rely on the domestic market throughout the sample period. By focusing on those firms that never access international capital markets, we test how their liquidity changes as other firms internationalize. In all regressions, we control for

\footnotetext{
${ }^{11}$ Since in some cases the value traded is zero, we use the natural logarithm of one plus the turnover ratio in the regressions. An alternative measure of liquidity is the number of shares traded in one year divided by the number of shares outstanding. This alternative abstracts from price changes. But, it is impossible to usefully aggregate across different stocks to obtain country-level liquidity measures using this alternative measure.
} 
country and time effects ( $n_{c}$ and $\tau_{t}$ respectively), but do not report these in the tables to save space.

$I S_{c, t}$ is the share of international firms in country c at time t. Thus, $I S_{c, t}$ is the number of international firms from country $\mathrm{c}$ at time $\mathrm{t}$ divided by the total number of firms listed in the domestic market for country $\mathrm{c}$ at time $\mathrm{t}$. In computing $I S_{c, t}$, a firm is considered an international firm from the year it issues a depositary receipt, cross-lists, or raises capital abroad. If, however, the firm terminates its depositary receipt listing or de-lists from an international exchange, then the numerator of $I S_{c, t}$ falls by one. ${ }^{12}$

$I T_{c, t}^{I}$ is the aggregate turnover ratio of country c's international firms in international equity markets at time t. Thus, $I T_{c, t}^{I}$ equals the aggregate value traded of all of country c's international firms in international markets divided by the market capitalization of those international firms.

We include the variable $I T_{c, t}^{I}$ because we want to control for trading of country c's equities on international exchanges. Information about a country's political and economic conditions may induce trading of that country's stocks in both international and domestic markets. This effect would be captured by a positive coefficient on $I T_{c, t}^{I}$. To assess the independent impact of the share of firms in a country that are international on domestic liquidity, we seek to abstract from time-varying country specific factors influencing trading. Hence, we include the trading of country c's stocks in international markets in regression (1).

$M_{c, t}$ is a matrix of macroeconomic and country-specific control variables. We include gross domestic product (GDP) per capita since the level of economic development may influence

\footnotetext{
${ }^{12}$ Since firms can list abroad without listing in the domestic markets, this ratio could, in theory, be larger than one.
} 
financial markets development (Levine, 2003). We also include an index of the law and order tradition of the economy since the operation of legal systems may influence equity market development (Beck, Demirguc-Kunt, and Levine, 2003; La Porta, Lopez-de-Silanes, Shleifer, and Vishny, 1998). Furthermore, we control for the openness of the capital account to international capital flows (using data from the International Monetary Fund) since international financial integration may influence the liquidity of domestic equity markets (Bekaert, Harvey, and Lundblad, 2001, 2002). We incorporate the macroeconomic and country-specific control variables because we want to assess the independent impact of internationalization on domestic liquidity. Toward this end, we examined a variety of additional country-specific factors in robustness checks as discussed below.

$F_{j, c, t}$ includes firm-specific characteristics in country c during year t. We control for company level traits to assess the independent impact of internationalization on the trading of firms in the domestic market. In the tables, we include the logarithm of the total assets in U.S. dollars. In robustness checks, we control for many other firm characteristics.

\section{Results on the direct effect}

Contrary to a variety of theoretical models discussed in the Introduction, the Table 1 results indicate that internationalization is negatively associated with the liquidity of domestic firms. In particular, the coefficient on the share of international firms in country $\mathrm{c}$ at time $\mathrm{t}, \gamma_{1}$, is negative and significant at the one-percent level across all of the specifications that control for different combinations of regressors. In terms of the other regressors, we do not find a strong link between the trading of international firms in international markets and the liquidity of domestic stocks. Put differently, trading of country c's international stocks on international exchanges $\left(I T_{c, t}^{I}\right)$ is not robustly related with the liquidity of domestic stocks. Also, rich 
countries and countries with a strong law and order tradition tend to have domestic firms with greater liquidity. Finally, we see that the variable, total assets, enters with a negative coefficient. The reason for the negative coefficient is that total assets is closely linked with market capitalization, which is the denominator of the dependent variable. As we will see below however, when we compare the trading of stocks within a country, the equities of bigger companies trade more than those of smaller companies. In sum, as the share of international firms in an economy rises - i.e., as the fraction of firms in an economy that issue depositary receipts, cross-list, or raise capital abroad rises, the liquidity of remaining firms falls.

The adverse impact of internationalization on the liquidity of domestic firms is not only statistically significant; it is economically relevant. For instance, consider the last regression coefficient based on the regression with all of the regressors included (-2.2). This estimate implies that a two-standard deviation increase in the share of international firms (0.086) will cause the liquidity of domestic firms to fall by -0.19 . This is substantial given that the mean value of the liquidity of domestic firms $\left(T_{j, c, t}^{D}\right)$ is $0.50 .^{13}$

Some caution, however, is needed in interpreting these initial results. Some may argue that the results simply reflect the possibility that firms that internationalize are good firms and firms that do not internationalize are comparatively poor. While potentially true, this would not negate the value of the Table 1 results. First, some theories discussed in the Introduction suggest that internationalization boosts domestic liquidity by making markets more integrated. We find no evidence for this. Second, we confirm the Table 1 results when controlling for many firmspecific traits (as discussed below). Thus, even when controlling for firm quality, we get the same result. Third, the argument that bad firms remain domestic does not necessarily predict

\footnotetext{
${ }^{13}$ Of course, this type of experiment is only for illustrative purposes. Two standard deviations is not a marginal change and we do not specify what drives the change in internationalization.
} 
that trading in those firms will diminish as good firms become international, which is what we find in Table 1. Fourth, we obtain the same results even when we restrict the sample to firms that trade for the entire sample period. Thus, uncompetitive firms that lose liquidity and drop out of the sample do not drive the results. Fifth, as we show below, the results indicate that the liquidity of international firms in the domestic market falls with internationalization, which is inconsistent with a simple story that international firm liquidity thrives while domestic firm liquidity falls. An additional weakness with the results thus far is that we do not provide information on the mechanisms linking internationalization to domestic firm liquidity. Although regression (1) provides information on the direct impact of internationalization on the liquidity of domestic firms, it does not provide information on the channels through which internationalization affects the liquidity of domestic firms. We turn to this now.

\section{B. Migration and Liquidity Spillover Channel}

The migration and liquidity spillover view predicts a two-stage channel through which internationalization may influence the liquidity of domestic stocks. First, internationalization may reduce the domestic trading of international firms as the trading of international firms migrates to more liquid, lower cost international markets. Second, the reduction in trading of international firms in domestic markets because of migration may hurt the liquidity of domestic firms because of liquidity spillovers. Taken together, migration and liquidity spillovers provide a theory of how internationalization might reduce the liquidity of domestic firms. As discussed in the Introduction, theoretical debate exists on each of these two mechanisms that define the migration and spillover channel. We assess empirically each of these channels. 


\section{The migration part of the migration and liquidity spillover channel}

To examine the migration component of the migration and liquidity spillover channel we use three different regression specifications. Consider first the simple specification that assesses the impact of internationalization on the domestic liquidity of international firms.

$$
T_{j, c, t}^{I}=\gamma_{1} \times I S_{c, t}+\gamma_{2} \times I T_{\bar{j}, c, t}^{I}+\theta^{\prime} M_{c, t}+\lambda_{1} \times F_{j, c, t}+\delta_{1} \times n_{c}+\delta_{2} \times \tau_{t}+\varepsilon_{j, c, t} .
$$

$T_{j, c, t}^{I}$ is the turnover ratio of international firm $\mathrm{j}$ in country $\mathrm{c}$ in year $\mathrm{t}$. The superscript I designates that it is an international firm, which is a firm that has either issued a depositary receipt, cross-listed, or raised capital abroad at some point in the sample. Thus, the definition of an international firm in equation (2) is consistent with the definition of domestic firms in equation (1). In these first analyses, we simply split the sample between firms that never internationalize and firms that become international at some point in the sample. Below, we will assess the impact of an individual firm's decision to internationalize on its liquidity within the domestic market.

$I T_{\tilde{j}, c, t}^{I}$ is the aggregate turnover ratio of country c's international firms in international equity markets at time $t$, excluding the trading of company $j$. The other variables are the same as those in equation (1).

Table 2 provides strong evidence that internationalization exerts a negative impact on the domestic liquidity of international firms. The coefficient on $I S_{c, t}$ always enters significantly and negatively. As in Table 1, we control for the international trading of international firms $\left(I T_{\bar{j}, c, t}^{I}\right)$. We do this to control for other factors influencing the trading of that country's equities. $I T_{\bar{j}, c, t}^{I}$ enters positively, though in some specifications only at the ten-percent level, which indicates a positive link between the trading of a country's stocks abroad and the trading of those 
international firms in the local market. In sum, after controlling for many factors, we find that as a country's firms internationalize this negatively influences the domestic liquidity of international firms.

The second regression we use to examine the migration component of the migration and liquidity spillover channel controls for the domestic liquidity of international firms in addition to the international liquidity of international firms. Thus, to assess the independent impact of the share of international firms in a country on the domestic liquidity of individual international firms we now control for the aggregate liquidity of international firms in both international and domestic markets.

Specifically, we estimate equation (3).

$$
T_{j, c, t}^{I}=\gamma_{1} \times I S_{c, t}+\gamma_{2} \times I T_{\bar{j}, c, t}^{I}+\beta \times T_{j, c, t}^{I}+\theta^{\prime} M_{c, t}+\lambda_{1} \times F_{j, c, t}+\delta_{1} \times n_{c}+\delta_{2} \times \tau_{t}+\varepsilon_{j, c, t} .
$$

$T_{\tilde{j}, c, t}^{I}$ is the aggregate domestic turnover ratio of international firms, respectively, excluding the trading of company $\mathrm{j}$.

Table 3 shows that internationalization lowers the domestic liquidity of international firms, i.e., there is a negative and significant coefficient on $I S_{c, t}$. Thus, even when controlling for many factors, the domestic liquidity of international firms falls as the share of firms in the economy with international equity market operations rises.

The Table 3 results also provide some preliminary evidence on spillovers. The coefficient on $T_{j, c, t}^{I}$ enters positively and significantly. Thus, aggregate trading of international firms in the local market positively influences the trading of individual international firms in the local market. We examine liquidity spillovers in greater depth below. 
The third regression we employ to test for migration examines the relative trading of an international firm in international and domestic markets. Thus, we examine whether the fraction of trading of an international firm shifts from domestic to international markets as more firms internationalize. So far, we have examined the impact of internationalization on the level of the domestic trading of international firms. But the domestic liquidity of international firms can be influenced by several factors, including how attractive an international company is relative to other companies. Therefore, a more direct method for studying migration is to analyze the share of the company's liquidity in the domestic market relative to its total liquidity.

Thus, we estimate the following regression for international firms.

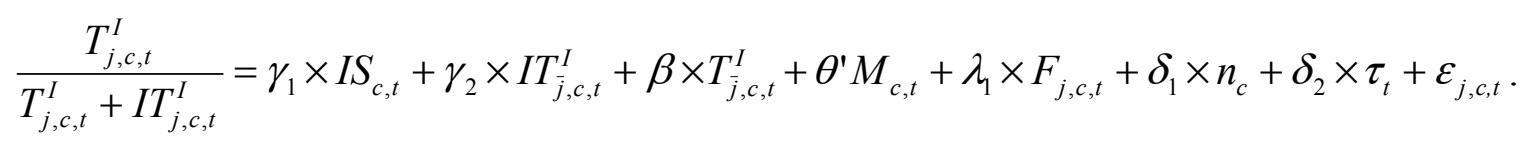

The dependent variable in this equation measures the level of domestic liquidity of firm $\mathrm{j}$ relative to firm $\mathrm{j}$ 's total liquidity, which includes the domestic liquidity of firm $\mathrm{j}$ and the international liquidity of firm $\mathrm{j}$. Since the market capitalization is the same in the numerator and denominator, this measure is equivalent to using the ratio of value traded in the domestic market to total value traded. Importantly, we control for the aggregate liquidity of country c's international firms, excluding firm $\mathrm{j}\left(T_{\bar{j}, c, t}^{I}\right)$. Thus, we control for the aggregate liquidity of firm $\mathrm{j}$ 's markets when assessing the impact of internationalization on whether the trading of firm $\mathrm{j}$ shifts abroad.

Table 4 presents regressions that are consistent with migration. There is a negative and significant coefficient on $I S_{c, t}$. This indicates that internationalization (an increase in the proportion of international firms in the domestic market) reduces the proportion of trading of international firms in domestic markets. As above, we control for many factors, including the 
liquidity of country c's stocks ( $\left.I T_{\bar{j}, c, t}^{I}\right)$ in international markets and also the domestic liquidity of country c's international firms $\left(T_{\bar{j}, c, t}^{I}\right)$.

Table 4 also provides evidence consistent with the existence of liquidity spillovers. Note that $T_{\bar{j}, c, t}^{I}$ has a positive and significant coefficient. Also, note that this holds while controlling for the liquidity of country c's international stocks in international markets $\left(I T_{\bar{j}, c, t}^{I}\right)$. Thus, proportion of trading of firm $\mathrm{j}$ that occurs in the domestic market is positively affected by the aggregate liquidity of the domestic market (excluding firm $\mathrm{j}$ ), i.e., aggregate liquidity influences the liquidity of individual stocks.

\section{The liquidity spillover part of the migration and liquidity spillover channel}

Next, we further examine liquidity spillovers. Does aggregate trading in a market influence the liquidity of individual domestic stocks? If there is migration - if internationalization induces a shift in the trading of international firms from domestic to international markets - and if there are liquidity spillovers, then this represents a two-part channel through which internationalization affects the liquidity of domestic firms.

Besides the evidence on liquidity discussed above that focuses on whether aggregate liquidity influences the trading of international firms in the local market, we estimate an extension of equation (1) that focuses on the liquidity of domestic firms.

$$
T_{j, c, t}^{D}=\gamma_{1} \times I S_{c, t}+\gamma_{2} \times I T_{c, t}^{I}+\beta \times T_{c, t}^{\mathrm{I}}+\theta^{\prime} M_{c, t}+\lambda_{1} \times F_{j, c, t}+\delta_{1} \times n_{c}+\delta_{2} \times \tau_{t}+\varepsilon_{j, c, t}
$$

The difference between equation (1) and equation (5) is that equation (5) controls for the aggregate liquidity of international firms in the domestic market. Specifically, $T_{c, t}^{\mathrm{I}}$ equals the domestic turnover of international firms in country $\mathrm{c}$ at time $\mathrm{t}$. 
Table 5 provides positive evidence of liquidity spillovers. As shown, there is a positive and significant coefficient on $T_{c, t}^{\mathrm{I}}$ in all of the specifications. The aggregate liquidity of international firms in the domestic market positively influences the liquidity of individual domestic firms above and beyond (i) the aggregate liquidity of international firms in international markets ( $I T_{c, t}^{I}$ ), (ii) the degree of internationalization ( $\left.I S_{c, t}\right)$, (iii) macroeconomic and country-specific controls ( $\left.M_{c, t}\right)$, (iv) firm-specific traits $\left(F_{j, c, t}\right)$, and (v) country and time effects ( $n_{c}$ and $\tau_{t}$ respectively). Thus, the positive coefficient on $T_{c, t}^{\mathrm{I}}$ presents evidence of positive liquidity spillovers.

The regression results presented in Tables $2-5$ are consistent with the migration and liquidity spillover channel. We find that (a) internationalization reduces the domestic liquidity of international firms and (b) the domestic liquidity of international firms exerts a positive impact on the liquidity of domestic firms. Taken together, these results imply that internationalization hurts the liquidity of domestic firms through the migration and liquidity spillover channel.

Note, however, that the migration and liquidity spillover channel is not the whole story. In Table 5 when we control for the liquidity of international firms in the domestic market, $I S_{c, t}$ still enters negatively and significantly. Thus, the liquidity of domestic firms is negatively influenced by the share of international firms in a market beyond the aggregate trading of international firms in the domestic economy $\left(T_{c, t}^{\mathrm{I}}\right)$ and in international markets $\left(I T_{c, t}^{I}\right)$ and after controlling for country-specific and firm-specific factors. If migration and liquidity spillovers were the only channel through which internationalization affected the liquidity of domestic stocks, then $I S_{c, t}$ should enter insignificantly after controlling for the liquidity spillover channel. 
The fact that $I S_{c, t}$ remains significant suggests that internationalization is influencing domestic liquidity through an additional mechanism.

\section{The Trade Diversion Channel}

\section{Method}

Trade diversion is an additional channel through which internationalization can influence domestic stock liquidity. We assess whether internationalization induces a compositional shift in the domestic market from the trading of domestic stocks to the trading of international stocks. More specifically, does the proportion of the overall liquidity of the domestic stock market accounted for by a particular firm rise simply because it becomes an international firm?

To study the trade diversion channel, we estimate the following equation:

$$
S_{j, c, t}=\phi_{1} \times I_{j, c, t}+\phi_{2} \times I T_{j, c, t}^{I}+\theta^{\prime} M_{c, t}+\kappa \times M \operatorname{Cap}_{j, c, t}+\lambda_{1} \times F_{j, c, t}+\delta_{1} \times n_{c}+\delta_{2} \times \tau_{t}+\varepsilon_{j, c, t} .
$$

$S_{j, c, t}=\frac{T_{j, c, t}}{T_{c, t}^{D+I}}$ is firm j's share of turnover in country $\mathrm{c}$ in year t relative to the total turnover of country c's domestic stock market in year t, where total turnover includes the domestic trading of both domestic and international firms. We also used value traded instead of the turnover ratio and obtained similar results.

$I_{j, c, t}$ is a dummy variable that equals one if the company is international and zero otherwise. Note, that this dummy turns from zero to one when a firm internationalizes. $I T_{j, c, t}^{I}$ is the international trading of company $j$ and equals zero for domestic firms. 
$\operatorname{MCap}_{j, c, t}$ is the market capitalization of firm j. We include this variable to control for the fact that the share of turnover in firm $\mathrm{j}$ might tend to rise when the price of the stock rises or when the number of shares outstanding increase..$^{14}$

Finally, we continue to control for the trading of international firms in international markets. We do this to control for as many firm- and country-specific factors as possible and focus on the marginal impact of internationalization of the proportion of domestic liquidity accounted for by international firms. We control for firm-specific factors, macroeconomic traits, year dummies, and country dummies.

\section{Results on the trade diversion channel}

The Table 6 results indicate that internationalization reduces the proportion of liquidity of domestic firms in the local market through the trade diversion channel. The coefficient, $\phi_{1}$, on $I_{j, c, t}$ enters with a positive coefficient in all of the Table 6 specifications. Thus, the proportion of the overall liquidity of the domestic stock market accounted for by a particular firm rises simply because it becomes international. Furthermore, note that the size of a company (total assets) is positively associated with the share of liquidity of that company in the local market. In sum, the results are consistent with the view that internationalization induces a compositional shift in the local market toward comparatively less trading of domestic stock and greater liquidity of international stocks.

As noted in the Introduction, alternative theories predict trade intensification, not trade diversion. These alternative views hold that internationalization will induce more active trading of domestic stocks, not less. In contrast, our results support the view that internationalization

\footnotetext{
${ }^{14}$ In the previous specifications, we do not include market capitalization among the independent variables because the dependent variables are already scaled by market capitalization.
} 
induces trade diversion. As firms internationalize, the domestic market becomes more focused on trading those international companies.

\section{Robustness Issues}

First, there may be concerns that the entry and exit of domestic and international firms will affect the results. Thus, estimated all regressions holding constant the number of firms in the sample. We obtained the same results with the control sample.

Second, we incorporated additional macroeconomic and country-specific control variables to evaluate the independent impact of internationalization on domestic liquidity. For instance, we included the inflation rate since inflation may interfere with trading and reduce market liquidity (Boyd, Levine, and Smith, 2001). We also controlled for economic growth since business-cycle phenomenon may influence market activity. We examined terms of trade changes since shocks may importantly influence equity market transactions. In other specifications, we included the real interest rate, a broad index of financial liberalization developed by Kaminsky and Schmukler (2002), and a time trend. Including these additional macroeconomic controls did not change the results on the impact of internationalization on the liquidity of domestic firms.

Third, we included an assortment of microeconomic regressors to control for firmspecific and industry-specific factors influencing stock liquidity. This is important since firmspecific traits may lead high-performing firms to internationalize and poorly performing firms to remain domestic. Thus, we included industry dummy variables and information on firm sales and profits. Controlling for these additional microeconomic factors did not change the findings. Moreover, even when including array of firm-specific variables, macroeconomic controls, 
industry dummy variables, year dummies, and country dummy variables, we continued to confirm the papers findings. While we are unable to rule out the possibility that some third factor is driving the results, the findings remained robust to many controls.

Fourth, to measure spillover effects in a different way, we estimated equations (3), (4), and (5) including the aggregate domestic liquidity of both domestic and international firms, instead of the liquidity of only international firms. We confirmed this paper's conclusions.

Fifth, our measure of internationalization is based on the number of firms becoming international. It may be appropriate to weight internationalization by the size and activity of the firm that is cross-listing, issuing depositary receipts, or raising capital abroad. Thus, we computed an internationalization measure based on the value traded of the internationalizing firm. We again confirmed this paper's findings.

Sixth, we re-defined internationalization by excluding the cases in which firms raise private capital in international markets and, at the same time, do not issue a depositary receipts or cross-list. These cases are only a small proportion (less than 10 percent) of the internationalization episodes. Excluding them did not alter the results of the paper.

Seventh, we also experimented with interaction terms. We examined whether internationalization has a different impact on domestic firms depending on their size or other characteristics. Thus, we assessed whether the liquidity of big firms that do not internationalization falls more or less than smaller firms that do not internationalize. We also examined firm profitability, sales, etc. We found no evidence of these interaction terms entering significantly. 
Eighth, in our sample, 19 out of 55 countries have zero or only one international firm. Thus, we re-did the analyses eliminating all 19 of these countries. We got the same results with this alternative sample.

\section{Conclusions}

This paper finds that the internationalization of stock markets has a negative effect on the stock market liquidity of domestic firms. We studied in detail how this effect takes place. Liquidity migrates to international financial markets, having negative spillover effects on the liquidity of domestic firms in domestic markets. Furthermore, there is trade diversion in domestic markets as trading shifts from domestic to international stocks within the local market. As a result, we were able to identify two channels through which internationalization hurts domestic firms.

The findings in this paper have opened several avenues for future research. First, a theoretical model that more comprehensively specifies the mechanisms influencing the impact of internationalization on domestic markets would substantively sharpen the interpretation of this paper's results and shape future empirical work. Second, although this paper finds strong evidence of liquidity spillovers, we do not identify the source of these spillovers. To better understand the operation of financial markets, future research might usefully dissect the sources of liquidity spillovers. Third, it would be interesting to understand the net effect of internationalization. Some papers have argued that internationalization has positive effects on the firms that internationalize. This paper has shown that internationalization hurts the liquidity of domestic firms. What is the net effect for the economy? What is the future for domestic 
markets and companies that are unable to internationalize? We believe these questions represent fruitful areas for future research. 


\section{References}

Ahearne, A., Griever, W., and Warnock, F., 2003. Information Costs and Home Bias: AN Analysis of U.S. Holdings of Foreign Equities. Journal of International Economics, forthcoming.

Alexander, G., Eun, C., and Janakiramanan, S., 1987. Asset Pricing and Dual Listing on Foreign Capital Markets: A Note. Journal of Finance Vol. 42(1), pp.151-158.

Alexander, G., Eun, C., and Janakiramanan, S., 1988. International Listings and Stock Returns: Some Empirical Evidence. Journal of Financial and Quantitative Analysis Vol. 23(2), pp.135-151.

Amihud, Y., and Mendelson, H., 1986. Asset Pricing and the Bid-Ask Spread. Journal of Financial Economics Vol. 17, pp. 223-249.

Bailey, W., Karolyi, A., and Salva, C., 2002. The Economic Consequences of Increased Disclosure: Evidence from International Cross-Listings. Ohio State and Cornell University working papers.

Baker, H. K., Nofsinger, J. R., and Weaver, D. G., 2002. International Cross-Listing and Visibility. Journal of Financial and Quantitative Analysis Vol. 37(3), pp.495-521.

Beck, T. and Levine, R. 2003. Stock Markets, Banks, and Economic Growth: Panel Evidence. Journal of Banking and Finance, forthcoming.

Beck, T., Demirguc-Kunt, A., and Levine, R., 2003. Law, Endowments, and Finance. Journal of Financial Economics, forthcoming.

Bekaert, G., and Harvey, C. R., 1995. Time-Varying World Market Integration. Journal of Finance Vol. 50(2), pp. 403-444.

Bekaert, G., and Harvey, C. R., 2000. Foreign Speculators and Emerging Equity Markets, Journal of Finance Vol. 55(2), pp. 565-613.

Bekaert, G., Harvey, C. R., and Lundblad, C., 2001. Emerging Equity Markets and Economic Development. Journal of Development Economics Vol. 66(2), pp.465-504.

Bekaert, G., Harvey, C. R., and Lundblad, C., 2002. Does Financial Liberalization Spur Growth? NBER working paper 8245.

Bovespa, 1996. Nova York Ataca e os Mercados Reagem. Revista Bovespa, May 1996.

Boyd, J. H., Levine, R., and Smith, B. D., 2001. The Impact of Inflation on Financial Sector Performance. Journal of Monetary Economics Vol. 47(2), pp.221-48. 
Chordia, T., Roll, R., and Subrahmanyam, A., 2000. Commonality in Liquidity. Journal of Financial Economics Vol. 56, pp. 3-28.

Chowdhry, B. and Nanda, V., 1991. Multimarket Trading and Market Liquidity. Review of Financial Studies Vol. 4(3), pp.483-511.

Claessens, S., Klingebiel, D., and Schmukler, S., 2002a. Accessing International Equity Markets: What Firms from Which Countries Go Abroad? Mimeo, World Bank.

Claessens, S., Klingebiel, D., and Schmukler, S., 2002b. The Future of Stock Exchanges in Emerging Markets. Brookings-Wharton Papers on Financial Services, pp.167-202, also available as CEPR Discussion Paper 3301.

Coffee, J., 1999. The Future as History: The Prospects for Global Convergence in Corporate Governance and Its Implications. Northwestern University Law Review, pp.641-708.

Demirguc-Kunt, A., Maksimovic, V., 1998. Law, Finance, and Firm Growth. Journal of Finance Vol. 53, 2107-2137.

Doidge, C A., Karolyi, A., and Stulz, R., 2002. Why Are Firms That List in the U.S. Worth More? Ohio State University working paper.

Domowitz, I., Glen, J., and Madhavan, A., 1998. International Cross-Listing and Order Flow Migration: Evidence from an Emerging Market. Journal of Finance Vol. 53(6), pp.20012027.

Edison, H. and Warnock, F., 2003. U.S. Investors' Emerging Market Portfolios: A SecurityLevel Analysis. International Monetary Fund, mimeo.

Errunza, V., and Miller, D., 2000. Market Segmentation and the Cost of Capital in International Equity Markets. Journal of Financial and Quantitative Analysis Vol. 35(4), pp.577-600.

Fereration des Bourses de Valeurs, 2000. Price Discovery and the Competitiveness of Trading Systems.

Financial Times, 1998. ADRs Prove a Double-Edged Sword, April 6.

Foerster, S. and Karolyi, A., 2000. The Long Run Performance of Global Equity Offerings. Journal of Financial and Quantitative Analysis Vol. 35(4), pp.499-528.

Foerster, S. and Karolyi, A., 1999. The effects of Market Segmentation and Investor Recognition on Asset Prices: Evidence form Foreign Stocks Listing in the United States. Journal of Finance Vol. 54(3), pp.981-1013. 
Foerster, S. and Karolyi, A., 1998. Multimarket Trading and Liquidity: A Transactions Data Analysis of Canada-U.S. Interlistings. Journal of International Financial Markets, Institutions, and Money Vol. 8(3-4), pp.393-412.

Foerster, S. and Karolyi, A., 1993. International Listings of Stocks: The Case of Canada and the U.S. Journal of International Business Studies Vol. 24, pp.763-784.

Hargis, K., 2000. International Cross-Listing and Stock Market Development in Emerging Economies. International Review of Economics and Finance Vol. 9(2), pp.101-122.

Hargis, K., 1998. When Does Multimarket Trading Improve the Quality of the Primary Market? Evidence from International Cross-Listings. Goldman, Sachs and Co. Working Paper.

Hargis, K. and Ramanlal, P., 1998. When Does Internationalization Enhance the Development of Domestic Stock Markets? Journal of Financial Intermediation Vol. 7(3), pp.263-292.

Henry, P., 2000. Stock Market Liberalization, Economic Reform, and Emerging Market Equity Prices. Journal of Finance Vol. 55(2), pp. 529-564.

Kaminsky, G. and Schmukler, S., 2002. Short-Run Pain, Long-Run Gain: The Effects of Financial Liberalization. World Bank Working Paper No. 2912.

Karolyi, A., 1998. Why do Companies List Shares Abroad? A Survey of the Evidence and its Managerial Implications. Financial Markets, Institutions, and Instruments, Vol. 7(1), pp. $1-60$.

Karolyi, A., 2003. The Role of ADRs in the Development and Integration of Emerging Equity Markets. Mimeo, Ohio State University.

Lang, M., Lins, V., and Miller, D., 2002. ADRs, Analysts, and Accuracy. University of Utah Working Paper.

Latin Finance, 1999. The Incredible Shrinking Markets. September.

La Porta, R., Lopez-de-Silanes, F., Shleifer, A., and Vishny, R. W., 1998. Law and Finance. Journal of Political Economy Vol. 106(6), pp.1113-1155.

Levine, R. 2003. Finance and Growth. In Aghion, P. and Durlauf, S. (eds.), Handbook of Economic Growth, Elsevier Press, forthcoming.

Levine, R. and Zervos, S., 1998a. Stock Markets, Banks, and Economic Growth. American Economic Review Vol. 88(3), pp.537-558.

Levine, R. and Zervos, S., 1998b. Capital Control Liberalization and Stock Market Development. World Development Vol. 26, pp. 1169-1184. 
Martin, P. and Rey, H., 2000. Financial Integration and Asset Returns. European Economic Review Vol. 44(7), pp.1327-1350.

Merton, R. 1987. A Simple Model of Capital Market Equilibrium with Incomplete Information. Journal of Finance Vol. 42(3), pp.483-510.

Miller, D., 1999. The Market Reaction to International Cross-Listings: Evidence from Depositary Receipts. Journal of Financial Economics Vol. 51(1), pp.103-123

Moel, A., 2001. The Role of American Depositary Receipts in the Development of Emerging Markets. Economia Vol. 2(1), pp.209-273.

Noronha, G., Sarin, A., and Saudagaran, S., 1996. Testing for Microstructure Effects of International Dual Listings Using Intraday Data. Journal of Banking and Finance Vol. 20(6), pp.965-983.

Pagano, M., Roell, A., and Zechner, J., 2002. The Geography of Equity Listing: Why Do European Companies List Abroad? Journal of Finance Vol. 57(6), pp.2651-2694.

Portes, R. and Rey, H. 1999. The Determinants of Cross-Border Equity Flows. NBER Working Paper 7336.

Pulatkonak, M. and Sofianos, G., 1999. The Distribution of Global Trading in NYSE-Listed Non-U.S. Stocks. NYSE Working Paper 99-03.

Reese, W. A. Jr. and Weisbach, M. S., 2001. Protection of Minority Shareholder Interests, CrossListing in the United States, and Subsequent Equity Offerings. Journal of Financial Economics, forthcoming.

Schmukler, S. and Vesperoni, E., 2001. Firms' Financing Choices in Bank-Based and MarketBased Economies. In Demirguc-Kunt, A. and Levine, R. (eds.), Financial Structure and Economic Development, MIT Press.

Stulz, R., 1999. Globalization of Equity Markets and the Cost of Capital. Journal of Applied Corporate Finance, Fall, pp.8-25.

The Economist, 2000. Latin America's Stock Markets: High and Dry, February 19. 


\section{Table 1: Effects of Internationalization on Domestic Firms}

This table reports regressions of the impact of internationalization on the liquidity of domestic firms. Using firm-level data from 55 countries, during the years $1989-2000$, and employing a feasible generalized least squares estimator with heteroskedasticity-consistent standard errors, the table reports results of the following regression equation: $T_{j, c, t}^{D}=\gamma_{1} \times I S_{c, t}+\gamma_{2} \times I T_{c, t}^{I}+\theta^{\prime} M_{c, t}+\lambda_{1} \times F_{j, c, t}+\delta_{1} \times n_{c}+\delta_{2} \times \tau_{t}+\varepsilon_{j, c, t} . \quad T_{j, c, t}^{D}$ is the logarithm of one plus the turnover ratio of domestic firm $\mathrm{j}$ in country c during year $\mathrm{t}$, where the turnover ratio equals the value traded of firm $\mathrm{j}$ in country c during year $\mathrm{t}$ divided by that firm's market capitalization. $I S_{c, t}$ is the share of international firms in country $\mathrm{c}$ at time $\mathrm{t}$ and is the measure of internationalization. $I T_{c, t}^{I}$ is the logarithm of one plus the aggregate turnover ratio of country c's international firms in international equity markets during year t. $M_{c, t}$ is a matrix of macroeconomic and country-specific control variables, which in the table includes the logarithm of real per capita gross domestic product (Log of GDP per capita), an index of the law and order tradition of the country (Law and Order), and an index of capital account openness (Capital Account Liberalization). $\quad F_{j, c, t}$ is a vector of firm $\mathrm{j}$ characteristics in country $\mathrm{c}$ during year $\mathrm{t}$, which in the table includes the logarithm of total assets of the firm as a proxy for firm size (Log of Total Assets). In the regression $n_{c}$ and $\tau_{t}$ represent country-specific and year-specific dummy variables (Country Dummies and Year Dummies respectively), but the results on these coefficients are not reported in the tables. T-statistics are in brackets. $* * *, * *, *$ mean significant at $1 \%, 5 \%$, and $10 \%$.

\begin{tabular}{|c|c|c|c|c|c|c|}
\hline \multicolumn{7}{|c|}{ "Dependent Variable: } \\
\hline \multicolumn{7}{|c|}{ Log of One Plus the Turnover Ratio of Domestic Firms } \\
\hline$I S_{c, t}$ & $\begin{array}{l}-0.942 * * * \\
{[4.349]}\end{array}$ & $\begin{array}{l}-2.483 * * * \\
{[6.714]}\end{array}$ & $\begin{array}{l}-2.422 * * * \\
{[6.413]}\end{array}$ & $\begin{array}{l}-2.340 * * * \\
{[6.130]}\end{array}$ & $\begin{array}{l}-2.362 * * * \\
{[6.323]}\end{array}$ & $\begin{array}{l}-2.203 * * * \\
{[5.622]}\end{array}$ \\
\hline$I T_{c, t}^{I}$ & $\begin{array}{r}0.023 \\
{[0.513]}\end{array}$ & $\begin{array}{c}-0.048 \\
{[0.866]}\end{array}$ & $\begin{array}{c}-0.077 \\
{[1.346]}\end{array}$ & $\begin{array}{r}-0.005 \\
{[0.087]}\end{array}$ & $\begin{array}{r}-0.050 \\
{[0.908]}\end{array}$ & $\begin{array}{r}-0.043 \\
{[0.792]}\end{array}$ \\
\hline Log of GDP per capita & & & $\begin{array}{l}0.123 * * * \\
{[2.642]}\end{array}$ & & & $\begin{array}{l}0.112 * * \\
{[2.397]}\end{array}$ \\
\hline Law and Order & & & & $\begin{array}{l}0.034 * * * \\
{[2.964]}\end{array}$ & & $\begin{array}{l}0.025 * * \\
{[2.189]}\end{array}$ \\
\hline $\begin{array}{l}\text { Capital Account } \\
\text { Liberalization }\end{array}$ & & & & & $\begin{array}{r}-0.032 \\
{[1.521]}\end{array}$ & $\begin{array}{r}-0.034 \\
{[1.558]}\end{array}$ \\
\hline Log of Total Assets & & $\begin{array}{l}-0.062 * * * \\
{[8.891]}\end{array}$ & $\begin{array}{l}-0.063 * * * \\
{[8.921]}\end{array}$ & $\begin{array}{l}-0.062 * * * \\
{[8.940]}\end{array}$ & $\begin{array}{l}-0.058 * * * \\
{[8.243]}\end{array}$ & $\begin{array}{l}-0.059 * * * \\
{[8.310]}\end{array}$ \\
\hline Country Dummies & Yes & Yes & Yes & Yes & Yes & Yes \\
\hline Year Dummies & Yes & Yes & Yes & Yes & Yes & Yes \\
\hline Number of Firms & 2,531 & 1,290 & 1,290 & 1,290 & 1,276 & 1,276 \\
\hline Number of Observations & 14,382 & 6,735 & 6,735 & 6,735 & 6,556 & 6,556 \\
\hline R-squared & 0.629 & 0.67 & 0.67 & 0.67 & 0.654 & 0.655 \\
\hline
\end{tabular}




\section{Table 2: Effects of Internationalization on International Firms}

This table reports regressions of the impact of internationalization on the liquidity of international firms within the domestic market. Using firm-level data from 55 countries, during the years 1989-2000, and employing a feasible generalized least squares estimator with heteroskedasticity-consistent standard errors, the table reports results of the following regression equation: $T_{j, c, t}^{I}=\gamma_{1} \times I S_{c, t}+\gamma_{2} \times I T_{j, c, t}^{I}+\theta^{\prime} M_{c, t}+\lambda_{1} \times F_{j, c, t}+\delta_{1} \times n_{c}+\delta_{2} \times \tau_{t}+\varepsilon_{j, c, t} . T_{j, c, t}^{I}$ is the logarithm of one plus the turnover ratio of international firm $\mathrm{j}$ in country $\mathrm{c}$ during year $\mathrm{t}$, where the turnover ratio equals the value traded of firm $\mathrm{j}$ in country $\mathrm{c}$ during year $\mathrm{t}$ divided by that firm's market capitalization. $I S_{c, t}$ is the share of international firms in country c at time $\mathrm{t}$ and is the measure of internationalization. $I T_{j, c, t}^{I}$ is the logarithm of one plus the aggregate turnover ratio of country c's international firms in international equity markets during year $\mathrm{t}$, excluding the trading of company $\mathrm{j}$. $M_{c, t}$ is a matrix of macroeconomic and country-specific control variables, which in the table includes the logarithm of real per capita gross domestic product (Log of GDP per capita), an index of the law and order tradition of the country (Law and Order), and an index of capital account openness (Capital Account Liberalization). $F_{j, c, t}$ is a vector of firm $\mathrm{j}$ characteristics in country c during year $\mathrm{t}$, which in the table includes the logarithm of total assets of the firm as a proxy for firm size (Log of Total Assets). In the regression $n_{c}$ and $\tau_{t}$ represent country-specific and year-specific dummy variables (Country Dummies and Year Dummies respectively), but the results on these coefficients are not reported in the tables. T-statistics are in brackets. ***, **, * mean significant at $1 \%, 5 \%$, and $10 \%$.

\begin{tabular}{|c|c|c|c|c|c|c|}
\hline \multicolumn{7}{|c|}{ "Dependent Variable: } \\
\hline$\overline{I S} S_{c, t}$ & $\begin{array}{l}-1.187 \text { *** } \\
{[4.776]}\end{array}$ & $\begin{array}{l}-1.319 * * * \\
{[3.774]}\end{array}$ & $\begin{array}{l}-1.388 \text { *** } \\
{[3.905]}\end{array}$ & $\begin{array}{l}-1.152 \text { *** } \\
{[3.344]}\end{array}$ & $\begin{array}{l}-1.377 \text { *** } \\
{[3.971]}\end{array}$ & $\begin{array}{l}-1.345 \text { *** } \\
{[3.899]}\end{array}$ \\
\hline$I T_{j, c, t}^{I}$ & $\begin{array}{l}0.137 \\
{[1.997]}\end{array}$ & $\begin{array}{c}0.113 * \\
{[1.778]}\end{array}$ & $\begin{array}{c}0.119 * \\
{[1.839]}\end{array}$ & $\begin{array}{l}0.155 * * \\
{[2.393]}\end{array}$ & $\begin{array}{c}0.111 * \\
{[1.736]}\end{array}$ & $\begin{array}{l}0.1711^{* * *} \\
{[2.586]}\end{array}$ \\
\hline Log of GDP per capita & & & $\begin{array}{r}-0.038 \\
{[0.716]}\end{array}$ & & & $\begin{array}{r}-0.084 \\
{[1.557]}\end{array}$ \\
\hline Law and Order & & & & $\begin{array}{l}0.047 \text { *** } \\
{[3.395]}\end{array}$ & & $\begin{array}{l}0.053 \text { *** } \\
{[3.610]}\end{array}$ \\
\hline $\begin{array}{l}\text { Capital Account } \\
\text { Liberalization }\end{array}$ & & & & & $\begin{array}{r}0.007 \\
{[0.249]}\end{array}$ & $\begin{array}{r}0.013 \\
{[0.440]}\end{array}$ \\
\hline Log of Total Assets & & $\begin{array}{c}-0.012 * \\
{[1.653]}\end{array}$ & $\begin{array}{r}-0.012 \\
{[1.570]}\end{array}$ & $\begin{array}{c}-0.013 * \\
{[1.822]}\end{array}$ & $\begin{array}{c}-0.012 * \\
{[1.663]}\end{array}$ & $\begin{array}{c}-0.012 * \\
{[1.685]}\end{array}$ \\
\hline Country Dummies & Yes & Yes & Yes & Yes & Yes & Yes \\
\hline Year Dummies & Yes & Yes & Yes & Yes & Yes & Yes \\
\hline Number of Firms & 634 & 548 & 548 & 548 & 548 & 548 \\
\hline Number of Observations & 3,863 & 2,945 & 2,945 & 2,945 & 2,910 & 2,910 \\
\hline R-squared & 0.643 & 0.658 & 0.658 & 0.659 & 0.654 & 0.656 \\
\hline
\end{tabular}




\section{Table 3: Effects of Internationalization on International Firms - Beyond Spillovers}

This table reports regressions of the impact of internationalization on the liquidity of international firms within the domestic market. Using firm-level data from 55 countries, during the years 1989-2000, and employing a feasible generalized least squares estimator with heteroskedasticity-consistent standard errors, the table reports results of the following regression equation: $T_{j, c, t}^{I}=\gamma_{1} \times I S_{c, t}+\gamma_{2} \times I T_{j, c, t}^{I}+\beta \times T_{j, c, t}^{I}+\theta^{\prime} M_{c, t}+\lambda_{1} \times F_{j, c, t}+\delta_{1} \times n_{c}+\delta_{2} \times \tau_{t}+\varepsilon_{j, c, t}$. $T_{j, c, t}^{I}$ is the logarithm of one plus the turnover ratio of international firm $\mathrm{j}$ in country $\mathrm{c}$ during year $\mathrm{t}$, where the turnover ratio equals the value traded of firm $\mathrm{j}$ in country $\mathrm{c}$ during year $\mathrm{t}$ divided by that firm's market capitalization. $I S_{c, t}$ is the share of international firms in country c at time $\mathrm{t}$ and is the measure of internationalization. IT $\frac{I}{j, c, t}$ is the logarithm of one plus the aggregate turnover ratio of country c's international firms in international equity markets during year $\mathrm{t}$, excluding the trading of company $\mathrm{j}$. $T_{j, c, t}^{I}$ is the logarithm of one plus the turnover ratio of international firms within the domestic market, excluding the trading of company j. $M_{c, t}$ is a matrix of macroeconomic and country-specific control variables, which in the table includes the logarithm of real per capita gross domestic product (Log of GDP per capita), an index of the law and order tradition of the country (Law and Order), and an index of capital account openness (Capital Account Liberalization). $F_{j, c, t}$ is a vector of firm $\mathrm{j}$ characteristics in country c during year $\mathrm{t}$, which in the table includes the logarithm of total assets of the firm as a proxy for firm size (Log of Total Assets). In the regression $n_{c}$ and $\tau_{t}$ represent country-specific and year-specific dummy variables (Country Dummies and Year Dummies respectively), but the results on these coefficients are not reported in the tables. T-statistics are in brackets. $* * *, * *, *$ mean significant at $1 \%, 5 \%$, and $10 \%$.

\begin{tabular}{|c|c|c|c|c|c|c|}
\hline \multicolumn{7}{|c|}{ Dependent Variable: } \\
\hline \multicolumn{7}{|c|}{ Log of One Plus the Turnover Ratio of International Firms } \\
\hline$\overline{I S_{c, t}}$ & $\begin{array}{l}-0.796 * * * \\
{[3.256]}\end{array}$ & $\begin{array}{l}-0.849^{* *} \\
{[2.449]}\end{array}$ & $\begin{array}{l}-0.845 * * \\
{[2.459]}\end{array}$ & $\begin{array}{l}-0.744^{* *} \\
{[2.162]}\end{array}$ & $\begin{array}{l}-0.885 * * \\
{[2.560]}\end{array}$ & $\begin{array}{l}-0.834 * * \\
{[2.448]}\end{array}$ \\
\hline$I T_{j, c, t}^{I}$ & $\begin{array}{r}0.025 \\
{[0.402]}\end{array}$ & $\begin{array}{r}0.006 \\
{[0.119]}\end{array}$ & $\begin{array}{r}0.006 \\
{[0.112]}\end{array}$ & $\begin{array}{r}0.037 \\
{[0.664]}\end{array}$ & $\begin{array}{r}0.001 \\
{[0.013]}\end{array}$ & $\begin{array}{r}0.037 \\
{[0.643]}\end{array}$ \\
\hline$T \frac{I}{j, c, t}$ & $\begin{array}{r}0.498 * * * \\
{[10.973]}\end{array}$ & $\begin{array}{l}0.445 * * * \\
{[8.914]}\end{array}$ & $\begin{array}{l}0.445 \text { *** } \\
{[8.990]}\end{array}$ & $\begin{array}{l}0.437 \text { *** } \\
{[8.768]}\end{array}$ & $\begin{array}{l}0.443 * * * \\
{[8.745]}\end{array}$ & $\begin{array}{l}0.432 \text { *** } \\
{[8.641]}\end{array}$ \\
\hline Log of GDP per capita & & & $\begin{array}{r}0.002 \\
{[0.044]}\end{array}$ & & & $\begin{array}{r}-0.027 \\
{[0.546]}\end{array}$ \\
\hline Law and Order & & & & $\begin{array}{l}0.032 * * \\
{[2.363]}\end{array}$ & & $\begin{array}{l}0.032 * * \\
{[2.301]}\end{array}$ \\
\hline $\begin{array}{l}\text { Capital Account } \\
\text { Liberalization }\end{array}$ & & & & & $\begin{array}{r}0.009 \\
{[0.341]}\end{array}$ & $\begin{array}{r}0.010 \\
{[0.376]}\end{array}$ \\
\hline Log of Total Assets & & $\begin{array}{r}-0.011 \\
{[1.548]}\end{array}$ & $\begin{array}{r}-0.011 \\
{[1.526]}\end{array}$ & $\begin{array}{c}-0.012 * \\
{[1.664]}\end{array}$ & $\begin{array}{r}-0.011 \\
{[1.559]}\end{array}$ & $\begin{array}{c}-0.012 \\
{[1.601]}\end{array}$ \\
\hline Country Dummies & Yes & Yes & Yes & Yes & Yes & Yes \\
\hline Year Dummies & Yes & Yes & Yes & Yes & Yes & Yes \\
\hline Number of Firms & 634 & 548 & 548 & 548 & 548 & 548 \\
\hline Number of Observations & 3,863 & 2,945 & 2,945 & 2,945 & 2,910 & 2,910 \\
\hline R-squared & 0.663 & 0.675 & 0.675 & 0.675 & 0.67 & 0.671 \\
\hline
\end{tabular}




\section{Table 4: Effects of Internationalization on Migration}

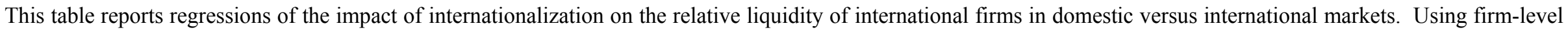

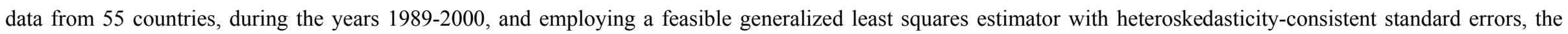

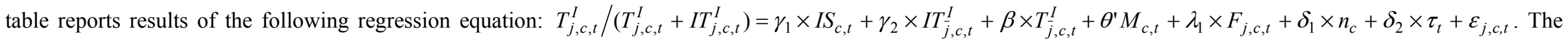

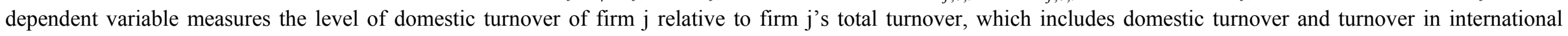

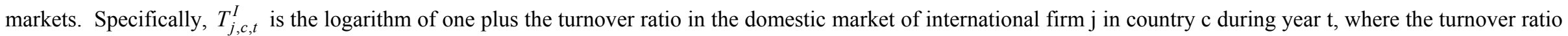

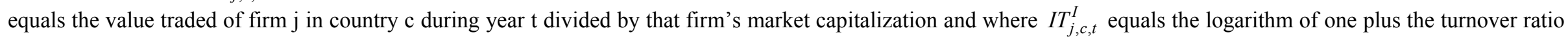

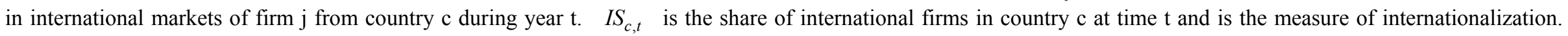

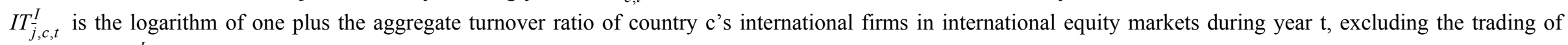

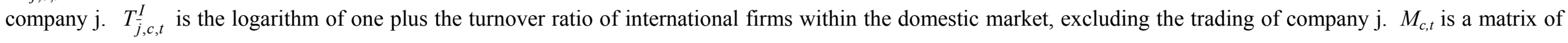

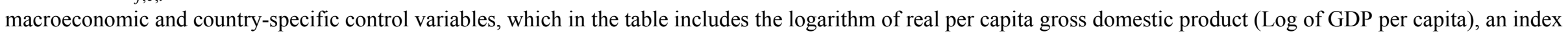

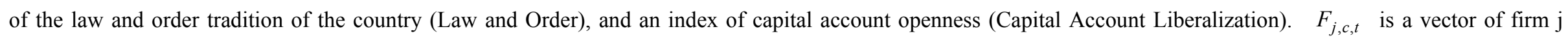

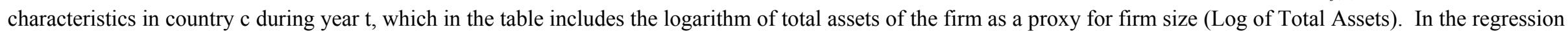

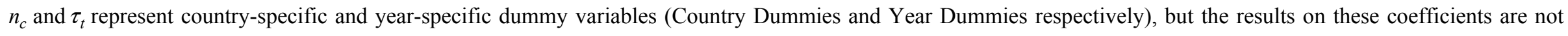
reported in the tables. T-statistics are in brackets. ***, **, * mean significant at $1 \%, 5 \%$, and $10 \%$.

\begin{tabular}{|c|c|c|c|c|c|c|}
\hline \multicolumn{7}{|c|}{ Dependent Variable: } \\
\hline \multicolumn{7}{|c|}{ Log of One Plus the Share of Value Traded Domestically of International Firms } \\
\hline$\overline{I S}$ & $\begin{array}{l}-0.807 * * * \\
{[7.186]}\end{array}$ & $\begin{array}{l}-0.816 \text { *** } \\
{[5.914]}\end{array}$ & $\begin{array}{l}-0.901 * * * \\
{[6.168]}\end{array}$ & $\begin{array}{l}-0.799 * * * \\
{[5.957]}\end{array}$ & $\begin{array}{l}-0.815 \text { *** } \\
{[5.888]}\end{array}$ & $\begin{array}{l}-0.876^{* * *} \\
{[6.136]}\end{array}$ \\
\hline$I T_{j, c, t}^{I}$ & $\begin{array}{l}-0.108 * * * \\
{[3.407]}\end{array}$ & $\begin{array}{l}-0.120 * * * \\
{[3.253]}\end{array}$ & $\begin{array}{l}-0.114 * * * \\
{[3.097]}\end{array}$ & $\begin{array}{l}-0.116 * * * \\
{[2.988]}\end{array}$ & $\begin{array}{l}-0.115 * * * \\
{[3.101]}\end{array}$ & $\begin{array}{l}-0.099 * * \\
{[2.540]}\end{array}$ \\
\hline$T_{\frac{j}{j, c, t}}^{I}$ & $\begin{array}{l}0.068 * * * \\
{[7.511]}\end{array}$ & $\begin{array}{l}0.071 * * * \\
{[5.974]}\end{array}$ & $\begin{array}{l}0.068 * * * \\
{[5.867]}\end{array}$ & $\begin{array}{l}0.069 * * * \\
{[5.618]}\end{array}$ & $\begin{array}{l}0.072 * * * \\
{[6.064]}\end{array}$ & $\begin{array}{l}0.066 \text { *** } \\
{[5.453]}\end{array}$ \\
\hline Log of GDP per capita & & & $\begin{array}{l}-0.044 * * \\
{[2.198]}\end{array}$ & & & $\begin{array}{l}-0.048 * * \\
{[2.242]}\end{array}$ \\
\hline Law and Order & & & & $\begin{array}{r}0.005 \\
{[1.101]}\end{array}$ & & $\begin{array}{l}0.010 \\
{[2.066]}\end{array}$ \\
\hline $\begin{array}{l}\text { Capital Account } \\
\text { Liberalization }\end{array}$ & & & & & $\begin{array}{l}-0.023 * \\
{[1.723]}\end{array}$ & $\begin{array}{r}-0.019 \\
{[1.388]}\end{array}$ \\
\hline Log of Total Assets & & $\begin{array}{r}-0.002 \\
{[0.544]}\end{array}$ & $\begin{array}{r}-0.001 \\
{[0.382]}\end{array}$ & $\begin{array}{r}-0.002 \\
{[0.586]}\end{array}$ & $\begin{array}{r}-0.002 \\
{[0.554]}\end{array}$ & $\begin{array}{r}-0.001 \\
{[0.460]}\end{array}$ \\
\hline Country Dummies & Yes & Yes & Yes & Yes & Yes & Yes \\
\hline Year Dummies & Yes & Yes & Yes & Yes & Yes & Yes \\
\hline Number of Firms & 621 & 535 & 535 & 535 & 535 & 535 \\
\hline Number of Observations & 3,628 & 2,768 & 2,768 & 2,768 & 2,733 & 2,733 \\
\hline R-squared & 0.974 & 0.971 & 0.971 & 0.971 & 0.971 & 0.971 \\
\hline
\end{tabular}




\section{Table 5: Effects of Internationalization on Domestic Firms - Beyond Spillovers}

This table reports regressions of the impact of internationalization on the liquidity of domestic firms. Using firm-level data from 55 countries, during the years $1989-2000$, and employing a feasible generalized least squares estimator with heteroskedasticity-consistent standard errors, the table reports results of the following regression equation: $T_{j, c, t}^{D}=\gamma_{1} \times I S_{c, t}+\gamma_{2} \times I T_{c, t}^{I}+\beta \times T_{c, t}^{\mathrm{I}}+\theta^{\prime} M_{c, t}+\lambda_{1} \times F_{j, c, t}+\delta_{1} \times n_{c}+\delta_{2} \times \tau_{t}+\varepsilon_{j, c, t} . T_{j, c, t}^{D}$ is the logarithm of one plus the turnover ratio of domestic firm $\mathrm{j}$ in country $\mathrm{c}$ during year $\mathrm{t}$, where the turnover ratio equals the value traded of firm $\mathrm{j}$ in country $\mathrm{c}$ during year $\mathrm{t}$ divided by that firm's market capitalization. $I S_{c, t}$ is the share of international firms in country $\mathrm{c}$ in year $\mathrm{t}$ and is the measure of internationalization. $I T_{c, t}^{I}$ is the logarithm of one plus the aggregate turnover ratio of country c's international firms in international equity markets during year t. $T_{c, t}^{\mathrm{I}}$ equals the logarithm of one plus the domestic turnover of international firms in country c at during year t. $M_{c, t}$ is a matrix of macroeconomic and country-specific control variables, which in the table includes the logarithm of real per capita gross domestic product (Log of GDP per capita), an index of the law and order tradition of the country (Law and Order), and an index of capital account openness (Capital Account Liberalization). $F_{j, c, t}$ is a vector of firm $\mathrm{j}$ characteristics in country $\mathrm{c}$ during year $\mathrm{t}$, which in the table includes the logarithm of total assets of the firm as a proxy for firm size (Log of Total Assets). In the regression $n_{c}$ and $\tau_{t}$ represent country-specific and year-specific dummy variables (Country Dummies and Year Dummies respectively), but the results on these coefficients are not reported in the tables. T-statistics are in brackets. ${ }^{* * *}, * *, *$ mean significant at $1 \%, 5 \%$, and $10 \%$.

\begin{tabular}{|c|c|c|c|c|c|c|}
\hline \multicolumn{7}{|c|}{$\begin{array}{c}\text { Dependent Variable: } \\
\text { Log of One Plus the Turnover Ratio of Domestic Firms }\end{array}$} \\
\hline$\overline{I S_{c, t}}$ & $\begin{array}{l}-0.525^{* *} \\
{[2.454]}\end{array}$ & $\begin{array}{l}-1.269^{* * *} \\
{[3.711]}\end{array}$ & $\begin{array}{l}-1.222 * * * \\
{[3.521]}\end{array}$ & $\begin{array}{l}-1.234^{* * *} \\
{[3.509]}\end{array}$ & $\begin{array}{l}-0.990^{* * *} \\
{[2.832]}\end{array}$ & $\begin{array}{l}-0.927 * * \\
{[2.565]}\end{array}$ \\
\hline$I T_{c, t}^{I}$ & $\begin{array}{r}-0.006 \\
{[0.150]}\end{array}$ & $\begin{array}{c}-0.095 * \\
{[1.808]}\end{array}$ & $\begin{array}{l}-0.120 * * \\
{[2.233]}\end{array}$ & $\begin{array}{r}-0.078 \\
{[1.554]}\end{array}$ & $\begin{array}{l}-0.095 * \\
{[1.804]}\end{array}$ & $\begin{array}{l}-0.123 * * \\
{[2.443]}\end{array}$ \\
\hline$T_{c, t}^{I}$ & $\begin{array}{l}0.455^{* * *} \\
{[18.391]}\end{array}$ & $\begin{array}{l}0.418^{* * *} \\
{[11.767]}\end{array}$ & $\begin{array}{l}0.416^{* * *} \\
{[11.703]}\end{array}$ & $0.412^{* * *}$ & $0.430^{* * *}$ & $\begin{array}{l}0.429 * * * \\
{[11.966]}\end{array}$ \\
\hline Log of GDP per capita & & & $\begin{array}{l}0.108 * * \\
{[2.408]}\end{array}$ & & & $\begin{array}{l}0.118^{* * *} \\
{[2.652]}\end{array}$ \\
\hline Law and Order & & & & $\begin{array}{r}0.013 \\
{[1.090]}\end{array}$ & & $\begin{array}{r}-0.001 \\
{[0.055]}\end{array}$ \\
\hline $\begin{array}{l}\text { Capital Account } \\
\text { Liberalization }\end{array}$ & & & & & $\begin{array}{l}-0.064 * * * \\
{[2.980]}\end{array}$ & $\begin{array}{l}-0.068 \text { *** } \\
{[3.102]}\end{array}$ \\
\hline Log of Total Assets & & $\begin{array}{l}-0.063 * * * \\
{[9.145]}\end{array}$ & $\begin{array}{l}-0.064 * * * \\
{[9.151]}\end{array}$ & $\begin{array}{l}-0.063 * * * \\
{[9.155]}\end{array}$ & $\begin{array}{l}-0.059 * * * \\
{[8.516]}\end{array}$ & $\begin{array}{l}-0.060 \text { *** } \\
{[8.539]}\end{array}$ \\
\hline $\begin{array}{l}\text { Country Dummies } \\
\text { Year Dummies }\end{array}$ & $\begin{array}{l}\text { Yes } \\
\text { Yes }\end{array}$ & $\begin{array}{l}\text { Yes } \\
\text { Yes }\end{array}$ & $\begin{array}{l}\text { Yes } \\
\text { Yes }\end{array}$ & $\begin{array}{l}\text { Yes } \\
\text { Yes }\end{array}$ & $\begin{array}{l}\text { Yes } \\
\text { Yes }\end{array}$ & $\begin{array}{l}\text { Yes } \\
\text { Yes }\end{array}$ \\
\hline Number of Firms & 2,531 & 1,290 & 1,290 & 1,290 & 1,276 & 1,276 \\
\hline Number of Observations & 14,382 & 6,735 & 6,735 & 6,735 & 6,556 & 6,556 \\
\hline R-squared & 0.642 & 0.678 & 0.678 & 0.678 & 0.663 & 0.663 \\
\hline
\end{tabular}




\section{Table 6: Effects of Internationalization on Domestic Firms - Trade Diversion Effects}

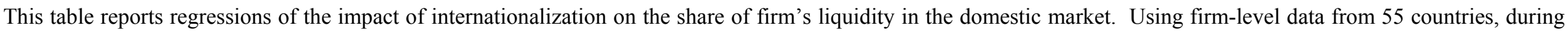

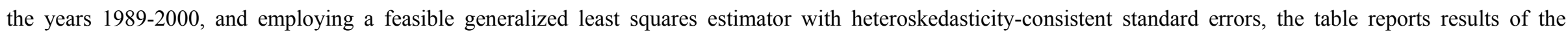

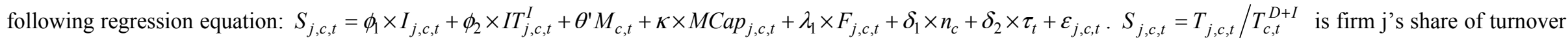

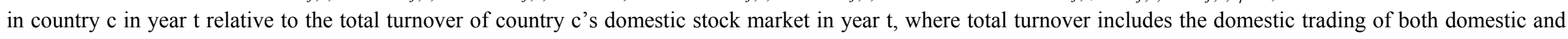

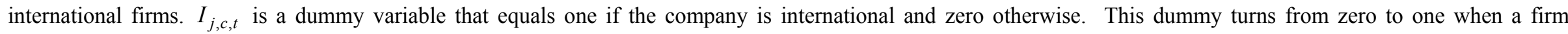

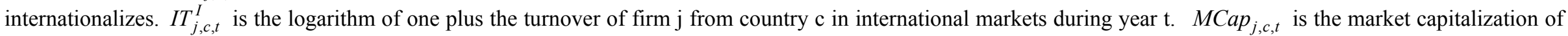

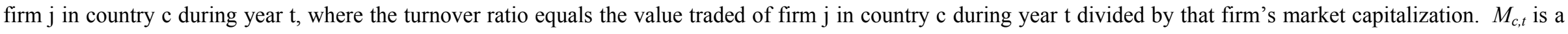

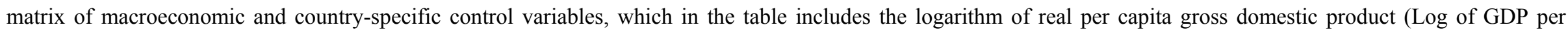

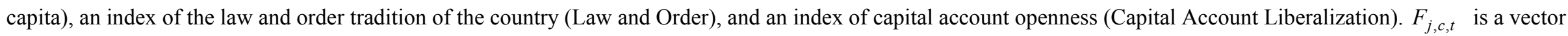

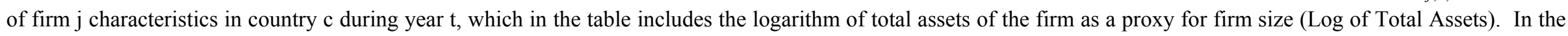

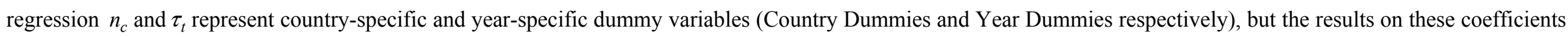
are not reported in the tables. T-statistics are in brackets. $* * *, * *, *$ mean significant at $1 \%, 5 \%$, and $10 \%$.

\begin{tabular}{|c|c|c|c|c|c|c|}
\hline \multicolumn{7}{|c|}{ Dependent Variable: } \\
\hline \multicolumn{7}{|c|}{ Log of One Plus the Share of Firm $j$ Value Traded } \\
\hline$\overline{I_{j, c, t}}$ & $\begin{array}{l}0.080 * * * \\
{[3.948]}\end{array}$ & $\begin{array}{l}0.079 * * * \\
{[3.587]}\end{array}$ & $\begin{array}{l}0.080 * * * \\
{[3.624]}\end{array}$ & $\begin{array}{l}0.079 * * * \\
{[3.587]}\end{array}$ & $\begin{array}{l}0.079 * * * \\
{[3.646]}\end{array}$ & $\begin{array}{l}0.080 * * * \\
{[3.688]}\end{array}$ \\
\hline$I T_{j, c, t}^{I}$ & $\begin{array}{l}0.223 * * * \\
{[2.921]}\end{array}$ & $\begin{array}{r}0.091 \\
{[1.110]}\end{array}$ & $\begin{array}{r}0.094 \\
{[1.155]}\end{array}$ & $\begin{array}{r}0.091 \\
{[1.106]}\end{array}$ & $\begin{array}{r}0.087 \\
{[1.061]}\end{array}$ & $\begin{array}{r}0.089 \\
{[1.091]}\end{array}$ \\
\hline $\operatorname{MCap}_{j, c, t}$ & $\begin{array}{l}-0.122 \text { *** } \\
{[19.864]}\end{array}$ & $\begin{array}{l}-0.133 * * * \\
{[14.705]}\end{array}$ & $\begin{array}{l}-0.134 * * * \\
{[14.766]}\end{array}$ & $\begin{array}{l}-0.133 \text { *** } \\
{[14.670]}\end{array}$ & $\begin{array}{l}-0.133 * * * \\
{[14.593]}\end{array}$ & $\begin{array}{l}-0.134 * * * \\
{[14.625]}\end{array}$ \\
\hline Log of GDP per capita & & & $\begin{array}{l}0.134 * * * \\
{[3.062]}\end{array}$ & & & $\begin{array}{l}0.138 * * * \\
{[3.102]}\end{array}$ \\
\hline Law and Order & & & & $\begin{array}{r}-0.001 \\
{[0.098]}\end{array}$ & & $\begin{array}{r}-0.009 \\
{[0.699]}\end{array}$ \\
\hline Capital Account & & & & & 0.018 & 0.010 \\
\hline Liberalization & & & & & {$[0.680]$} & {$[0.371]$} \\
\hline Log of Total Assets & & $\begin{array}{l}0.023 * * * \\
{[2.765]}\end{array}$ & $\begin{array}{l}0.023 * * * \\
{[2.689]}\end{array}$ & $\begin{array}{l}0.023 \\
{[2.752]}\end{array}$ & $\begin{array}{l}0.025 * * * \\
{[2.916]}\end{array}$ & $\begin{array}{l}0.025 \text { *** } \\
{[2.842]}\end{array}$ \\
\hline Country Dummies & Yes & Yes & Yes & Yes & Yes & Yes \\
\hline Year Dummies & Yes & Yes & Yes & Yes & Yes & Yes \\
\hline Number of Firms & 3,252 & 1,839 & 1,839 & 1,839 & 1,825 & 1,825 \\
\hline Number of Observations & 18,488 & 9,744 & 9,744 & 9,744 & 9,526 & 9,526 \\
\hline R-squared & 0.681 & 0.718 & 0.718 & 0.718 & 0.715 & 0.716 \\
\hline
\end{tabular}


Appendix Table 1

Basic Statistics and Means

This table reports summary statistics by country. It displays the total number of firms, the number of international firms, the number of domestic firms, the sample coverage, and the sample average of some of the variables used in the regressions. The variables turnover and value traded are the log of one plus turnover and one plus value traded. International companies are the ones that issue a depositary receipt, cross-list, or raise capital in a foreign stock exchange at any time in the sample.

\begin{tabular}{|c|c|c|c|c|c|c|c|c|c|c|c|}
\hline & Country & $\begin{array}{c}\text { Number of } \\
\text { Firms }\end{array}$ & $\begin{array}{c}\text { Number of } \\
\text { International } \\
\text { Firms }\end{array}$ & $\begin{array}{l}\text { Number of } \\
\text { Domestic } \\
\text { Firms }\end{array}$ & Sample Period & $\begin{array}{c}\text { Log Turnover } \\
\text { (Domestic } \\
\text { Firms) }\end{array}$ & $\begin{array}{c}\text { Log Turnover in } \\
\text { the Domestic } \\
\text { Market } \\
\text { (International } \\
\text { Firms) }\end{array}$ & $\begin{array}{c}\text { Log Ratio of Value } \\
\text { Traded in the Domestic } \\
\text { Market to Total Value } \\
\text { Traded } \\
\text { (International Firms) }\end{array}$ & $\begin{array}{c}\text { Log Share of } \\
\text { International } \\
\text { Firms }\end{array}$ & $\begin{array}{c}\text { Log Turnover in } \\
\text { International } \\
\text { Markets } \\
\text { (International } \\
\text { Firms) }\end{array}$ & $\begin{array}{c}\text { Market } \\
\text { Capitalization } \\
\text { (U.S. dollars, } \\
\text { Million) }\end{array}$ \\
\hline 1 & Argentina & 47 & 18 & 29 & $1989-2000$ & 0.399 & 0.283 & 0.500 & 0.071 & 0.315 & 668.2 \\
\hline 2 & Bahrain & 15 & 1 & 14 & $1999-2000$ & 0.094 & 0.369 & 0.693 & 0.000 & 0.000 & 337.4 \\
\hline 3 & Bangladesh & 66 & 1 & 65 & $1996-2000$ & 0.298 & 0.434 & 0.693 & 0.002 & 0.000 & 20.8 \\
\hline 4 & Botswana & 9 & 0 & 9 & $1996-2000$ & 0.067 & 0.000 & 0.000 & 0.000 & 0.000 & 90.4 \\
\hline 5 & Brazil & 105 & 36 & 69 & $1989-2000$ & 0.305 & 0.360 & 0.589 & 0.024 & 0.237 & $1,419.6$ \\
\hline 6 & Bulgaria & 23 & 0 & 23 & $1996-2000$ & 0.054 & 0.000 & 0.000 & 0.000 & 0.000 & 14.6 \\
\hline 7 & Chile & 58 & 22 & 36 & $1989-2000$ & 0.078 & 0.131 & 0.419 & 0.047 & 0.182 & 827.9 \\
\hline 8 & China & 251 & 94 & 157 & $1992-2000$ & 0.973 & 0.802 & 0.680 & 0.133 & 0.041 & 669.6 \\
\hline 9 & Colombia & 37 & 7 & 30 & $1989-2000$ & 0.072 & 0.142 & 0.620 & 0.029 & 0.042 & 285.0 \\
\hline 10 & Cote d'Ivoire & 15 & 0 & 15 & $1996-2000$ & 0.026 & 0.000 & 0.000 & 0.000 & 0.000 & 78.4 \\
\hline 11 & Croatia & 10 & 2 & 8 & $1997-2000$ & 0.061 & 0.039 & 0.693 & 0.020 & 0.000 & 265.6 \\
\hline 12 & Czech Republic & 76 & 4 & 72 & $1994-2000$ & 0.139 & 0.304 & 0.693 & 0.011 & 0.000 & 199.8 \\
\hline 13 & Ecuador & 13 & 0 & 13 & $1996-2000$ & 0.434 & 0.000 & 0.000 & 0.000 & 0.000 & 85.1 \\
\hline 14 & Egypt & 84 & 11 & 73 & $1996-2000$ & 0.274 & 0.338 & 0.693 & 0.003 & 0.000 & 162.0 \\
\hline 15 & Estonia & 13 & 1 & 12 & $1997-2000$ & 0.372 & 0.278 & 0.693 & 0.042 & 0.000 & 120.2 \\
\hline 16 & Ghana & 11 & 1 & 10 & $1996-2000$ & 0.084 & 0.001 & 0.118 & 0.035 & 0.163 & 101.5 \\
\hline 17 & Greece & 86 & 14 & 72 & $1989-2000$ & 0.417 & 0.411 & 0.691 & 0.017 & 0.005 & 655.0 \\
\hline 18 & Hungary & 25 & 17 & 8 & $1992-2000$ & 0.325 & 0.442 & 0.687 & 0.287 & 0.015 & 424.0 \\
\hline 19 & India & 182 & 48 & 134 & $1989-2000$ & 0.247 & 0.481 & 0.689 & 0.004 & 0.035 & 502.8 \\
\hline 20 & Indonesia & 137 & 34 & 103 & $1989-2000$ & 0.443 & 0.512 & 0.678 & 0.093 & 0.046 & 348.0 \\
\hline 21 & Israel & 55 & 19 & 36 & $1997-2000$ & 0.227 & 0.370 & 0.600 & 0.020 & 0.145 & 755.3 \\
\hline 22 & Jamaica & 24 & 0 & 24 & $1996-2000$ & 0.047 & 0.000 & 0.000 & 0.000 & 0.000 & 82.2 \\
\hline 23 & Jordan & 67 & 1 & 66 & $1989-2000$ & 0.283 & 0.028 & 0.693 & 0.002 & 0.000 & 82.2 \\
\hline 24 & Kenya & 20 & 1 & 19 & $1996-2000$ & 0.047 & 0.073 & 0.693 & 0.007 & 0.000 & 73.1 \\
\hline 25 & Latvia & 16 & 2 & 14 & $1997-2000$ & 0.269 & 0.332 & 0.693 & 0.018 & 0.000 & 19.8 \\
\hline 26 & Lebanon & 5 & 2 & 3 & $1999-2000$ & 0.104 & 0.060 & 0.693 & 0.000 & 0.000 & 297.7 \\
\hline 27 & Lithuania & 38 & 5 & 33 & $1996-2000$ & 0.119 & 0.292 & 0.693 & 0.035 & 0.000 & 29.9 \\
\hline 28 & Malaysia & 199 & 12 & 187 & $1989-2000$ & 0.595 & 0.261 & 0.693 & 0.008 & 0.000 & 794.6 \\
\hline
\end{tabular}


Appendix Table 1 (Continued)

Basic Statistics and Means

\begin{tabular}{|c|c|c|c|c|c|c|c|c|c|c|c|}
\hline & Country & $\begin{array}{c}\text { Number of } \\
\text { Firms }\end{array}$ & $\begin{array}{c}\text { Number of } \\
\text { International } \\
\text { Firms }\end{array}$ & $\begin{array}{c}\text { Number of } \\
\text { Domestic } \\
\text { Firms }\end{array}$ & Sample Period & $\mid \begin{array}{c}\text { Log Turnover } \\
\text { (Domestic } \\
\text { Firms) }\end{array}$ & $\begin{array}{c}\text { Log Turnover in } \\
\text { the Domestic } \\
\text { Market } \\
\text { (International } \\
\text { Firms) }\end{array}$ & $\begin{array}{c}\text { Log Ratio of Value } \\
\text { Traded in the Domestic } \\
\text { Market to Total Value } \\
\text { Traded } \\
\text { (International Firms) }\end{array}$ & $\begin{array}{c}\text { Log Share of } \\
\text { International } \\
\text { Firms }\end{array}$ & $\begin{array}{c}\text { Log Turnover in } \\
\text { International } \\
\text { Markets } \\
\text { (International } \\
\text { Firms) }\end{array}$ & $\begin{array}{c}\text { Market } \\
\text { Capitalization } \\
\text { (U.S. dollars, } \\
\text { Million) }\end{array}$ \\
\hline 29 & Mauritius & 17 & 0 & 17 & $1996-2000$ & 0.039 & 0.000 & 0.000 & 0.000 & 0.000 & 84.5 \\
\hline 30 & Mexico & 101 & 42 & 59 & $1989-2000$ & 0.253 & 0.373 & 0.522 & 0.153 & 0.480 & $1,443.8$ \\
\hline 31 & Morocco & 21 & 2 & 19 & $1996-2000$ & 0.089 & 0.149 & 0.693 & 0.010 & 0.000 & 488.4 \\
\hline 32 & Namibia & 8 & 0 & 8 & $1999-2000$ & 0.082 & 0.000 & 0.000 & 0.000 & 0.000 & 29.3 \\
\hline 33 & Nigeria & 41 & 0 & 41 & $1989-2000$ & 0.024 & 0.000 & 0.000 & 0.000 & 0.000 & 66.0 \\
\hline 34 & Oman & 34 & 0 & 34 & $1999-2000$ & 0.152 & 0.000 & 0.000 & 0.000 & 0.000 & 76.2 \\
\hline 35 & Pakistan & 124 & 5 & 119 & $1989-2000$ & 0.210 & 1.030 & 0.693 & 0.004 & 0.000 & 80.2 \\
\hline 36 & Peru & 43 & 8 & 35 & $1992-2000$ & 0.511 & 0.228 & 0.590 & 0.015 & 0.151 & 230.1 \\
\hline 37 & Philippines & 78 & 38 & 40 & $1989-2000$ & 0.424 & 0.324 & 0.685 & 0.096 & 0.032 & 566.8 \\
\hline 38 & Poland & 45 & 17 & 28 & $1992-2000$ & 0.572 & 0.317 & 0.693 & 0.038 & 0.000 & 395.7 \\
\hline 39 & Portugal & 47 & 12 & 35 & $1989-1999$ & 0.230 & 0.269 & 0.671 & 0.039 & 0.034 & 669.9 \\
\hline 40 & Romania & 53 & 2 & 51 & $1997-2000$ & 0.243 & 0.037 & 0.693 & 0.000 & 0.000 & 17.7 \\
\hline 41 & Russia & 42 & 5 & 37 & $1996-2000$ & 0.156 & 0.275 & 0.627 & 0.015 & 0.015 & $1,395.4$ \\
\hline 42 & Saudi Arabia & 22 & 0 & 22 & $1997-2000$ & 0.305 & 0.000 & 0.000 & 0.000 & 0.000 & $2,133.5$ \\
\hline 43 & Slovak Republic & 20 & 2 & 18 & $1996-2000$ & 0.354 & 0.143 & 0.693 & 0.009 & 0.000 & 60.7 \\
\hline 44 & Slovenia & 20 & 2 & 18 & $1996-2000$ & 0.332 & 0.324 & 0.693 & 0.030 & 0.000 & 104.7 \\
\hline 45 & South Africa & 102 & 33 & 69 & $1992-2000$ & 0.179 & 0.233 & 0.601 & 0.029 & 0.033 & $1,749.1$ \\
\hline 46 & South Korea & 230 & 30 & 200 & $1989-2000$ & 1.196 & 0.891 & 0.683 & 0.014 & 0.042 & 809.7 \\
\hline 47 & Sri Lanka & 66 & 2 & 64 & $1992-2000$ & 0.125 & 0.216 & 0.693 & 0.004 & 0.000 & 26.2 \\
\hline 48 & Taiwan, Province of China & 143 & 30 & 113 & $1989-2000$ & 1.506 & 1.203 & 0.691 & 0.027 & 0.022 & $1,615.9$ \\
\hline 49 & Thailand & 125 & 31 & 94 & $1989-2000$ & 0.789 & 0.602 & 0.693 & 0.048 & 0.000 & 633.8 \\
\hline 50 & Trinidad and Tobago & 12 & 0 & 12 & $1996-2000$ & 0.047 & 0.000 & 0.000 & 0.000 & 0.000 & 215.0 \\
\hline 51 & Tunisia & 18 & 1 & 17 & $1996-2000$ & 0.093 & 0.134 & 0.693 & 0.007 & 0.000 & 136.4 \\
\hline 52 & Turkey & 78 & 16 & 62 & $1989-2000$ & 1.019 & 0.659 & 0.691 & 0.026 & 0.002 & 632.8 \\
\hline 53 & Ukraine & 19 & 0 & 19 & $1997-2000$ & 0.080 & 0.000 & 0.000 & 0.000 & 0.000 & 80.2 \\
\hline 54 & Venezuela & 23 & 6 & 17 & $1989-2000$ & 0.190 & 0.222 & 0.570 & 0.037 & 0.302 & 328.1 \\
\hline \multirow[t]{2}{*}{55} & Zimbabwe & 34 & 3 & 31 & $1989-2000$ & 0.099 & 0.159 & 0.693 & 0.020 & 0.000 & 64.4 \\
\hline & Total & 3,253 & 640 & 2,613 & & 0.344 & 0.288 & 0.491 & 0.023 & 0.041 & 523.501 \\
\hline
\end{tabular}




\section{Appendix Table 2 \\ Series Description and Data Sources}

This table shows the description of the data used and their coverage and sources.

\begin{tabular}{|c|c|c|}
\hline Series & Description & Source \\
\hline $\begin{array}{l}\text { Variables related to the } \\
\text { internationalization of stock } \\
\text { markets }\end{array}$ & $\begin{array}{l}\text { The data come from Bank of New York (1989-2000) and Euromoney (1980-2000). This information is } \\
\text { used to classify firms as domestic or international companies. International companies are the ones } \\
\text { that issue a depositary receipt, cross-list, or raise capital in a foreign stock exchange at any time in the } \\
\text { sample. Different variables are constructed using this variable. See text for details. }\end{array}$ & Bank of New York and Euromoney \\
\hline $\begin{array}{l}\text { Domestic market capitalization } \\
\text { (current U.S. dollars) }\end{array}$ & Market capitalization in domestic stock markets. & $\begin{array}{l}\text { Standard \& Poor's (former International Finance Corporation) Emerging Markets } \\
\text { Database }\end{array}$ \\
\hline $\begin{array}{l}\text { Domestic value traded } \\
\text { (current U.S. dollars) }\end{array}$ & Value traded in domestic stock markets. & $\begin{array}{l}\text { Standard \& Poor's (former International Finance Corporation) Emerging Markets } \\
\text { Database }\end{array}$ \\
\hline $\begin{array}{l}\text { Value traded in foreign markets } \\
\text { (current U.S. dollars) }\end{array}$ & $\begin{array}{l}\text { Value traded in depository receipts covering the period } 1989-2000 \text {. Series are computed on a firm- } \\
\text { level basis by adding the different depositary receipts that belong to each company on a yearly basis. }\end{array}$ & Bank of New York \\
\hline $\begin{array}{l}\text { GDP per capita at market prices } \\
\text { (current U.S. dollars) }\end{array}$ & $\begin{array}{l}\text { Gross domestic product (GDP) divided by mid-year population. The GDP at purchaser prices data is } \\
\text { converted from domestic currencies using yearly official exchange rates. For the cases in which the } \\
\text { official exchange rate is different from the market rate, the latter is used. }\end{array}$ & World Bank: World Development Indicators \\
\hline Law and order & $\begin{array}{l}\text { Qualitative variable that ranges from } 1 \text { to } 6 \text {, where higher numbers indicate higher "levels" of law and } \\
\text { order. Law and order are assessed separately, with each sub-component comprising zero to three } \\
\text { points. The law sub-component is an assessment of the strength and impartiality of the legal system, } \\
\text { while the order sub-component is an assessment of popular observance of the law. Thus, a country can } \\
\text { have a high rating in terms of its judicial system, for example } 3 \text {, but a low rating, for example } 1 \text {, if the } \\
\text { law is ignored for a political aim, e.g. widespread strikes involving illegal practices. The data cover the } \\
\text { period 1984-2000 for all countries. }\end{array}$ & Political Risk Services: International Country Risk Guide \\
\hline $\begin{array}{l}\text { Capital account liberalization } \\
\text { (IMF) }\end{array}$ & $\begin{array}{l}\text { Dummy that equals one on and after the year of capital account liberalization, and zero elsewhere. The } \\
\text { data cover the period } 1975-2000 \text { for all countries. }\end{array}$ & $\begin{array}{l}\text { International Monetary Fund: Annual Report on Exchange Arrangements and } \\
\text { Exchange Restrictions }\end{array}$ \\
\hline Total assets & $\begin{array}{l}\text { Total assets as reported in Worldscope for each firm-year, in million of U.S. dollars. The sample } \\
\text { covers the period 1989-2000 for all countries. }\end{array}$ & Worldscope \\
\hline
\end{tabular}

